\title{
Accuracy of CT-guided transthoracic needle biopsy of lung lesions: factors affecting diagnostic yield
}

\section{Biopsia transtoracica percutanea TC-guidata di lesioni polmonari: variabili che influenzano l'accuratezza diagnostica}

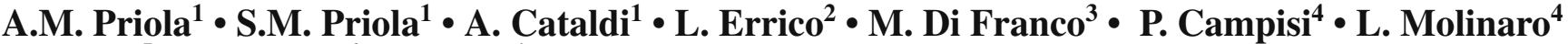

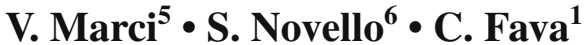

${ }^{1}$ Radiologia Diagnostica, ${ }^{2}$ Chirurgia Toracica, ${ }^{3}$ Farmacia, ${ }^{5}$ Anatomia Patologica, ${ }^{6}$ Oncologia Polmonare, Università degli Studi di Torino, A.S.O. San Luigi Gonzaga, Regione Gonzole 10, 10043 Orbassano (TO), Italy

${ }^{4}$ Anatomia Patologica, Università degli Studi di Torino, A.S.O. San Giovanni Battista, Torino, Italy

Correspondence to: A.M.Priola, Tel.: +39-011-9026785, Fax: +39-011-6705463, e-mail: adriano.priola@inwind.it

Received: 26 December 2006 / Accepted: 4 April 2007 / Published online: 13 December 2007

\begin{abstract}
Purpose. This study was performed to analyse the variables affecting the diagnostic accuracy of computed tomography (CT)guided transthoracic needle biopsy of pulmonary lesions. Materials and methods. A retrospective study of 612 consecutive procedures with confirmed final diagnoses was undertaken. Benign and malignant needle biopsy results were compared with final outcomes to determine diagnostic accuracy. A statistical analysis of factors related to patient characteristics, lung lesions and biopsy technique was performed to determine possible influences on diagnostic yield. A $p$ value less than 0.05 was interpreted as statistically significant.

Results. There were 508 (83\%) malignant and 104 (17\%) benign lesions. Sensitivity, specificity, positive predictive value, negative predictive value and accuracy for a diagnosis of malignancy were $90.2 \%, 99.0 \%, 99.8 \%, 67.3 \%$ and $91.7 \%$, respectively. Overall diagnostic accuracy was $83.3 \%$. Variables affecting diagnostic accuracy were the final diagnosis (benign $67 \%$, malignant $92 \%$; $p<0.001$ ) and lesion size (lesions $<1.5 \mathrm{~cm} 68 \%$, lesions $1.5-5.0 \mathrm{~cm}$ $87 \%$, lesions $>5 \mathrm{~cm} 78 \%$; $p<0.05$ ).

Conclusions. In CT-guided transthoracic needle biopsy, the final diagnosis and lesion size affect diagnostic accuracy: benign lung lesions and lesions smaller than $1.5 \mathrm{~cm}$ or larger than $5.0 \mathrm{~cm}$ in diameter provide lower diagnostic yield.
\end{abstract}

Key words Lung • Biopsy • Computed tomography (CT) • Guidance $\bullet$ Accuracy

\begin{abstract}
Riassunto
Obiettivo. Valutare i fattori che influenzano l'accuratezza diagnostica dell'agobiopsia transtoracica percutanea TC-guidata di lesioni polmonari.

Materiali e metodi. Sono state considerate retrospettivamente 612 procedure bioptiche consecutive per le quali è risultata disponibile la diagnosi definitiva. I reperti bioptici benigni e maligni sono stati confrontati con la diagnosi finale, ricavando l'accuratezza diagnostica della metodica. È stata quindi condotta un'analisi statistica relativamente a variabili proprie del paziente, della lesione e della tecnica bioptica per determinare possibili influenze sui valori di accuratezza. I dati ottenuti sono stati considerati statisticamente significativi per valori di $p<0,05$. Risultati. Cinquecentootto lesioni ( $83 \%$ ) sono risultate, alla diagnosi finale, maligne, mentre 104 (17\%) benigne. I valori di sensibilità, specificità, valore predittivo positivo, valore predittivo negativo ed accuratezza, riferiti ad una diagnosi di malignità, sono risultati rispettivamente del 90,2\%, 99,0\%, 99,8\%, 67,3\% e 91,7\%. L'accuratezza diagnostica globale della procedura è stata dell'83,3\%. Le variabili che hanno influenzato significativamente i livelli di accuratezza sono risultate la diagnosi finale (espansi benigni $67 \%$, maligni 92\%; $<<0,001)$ ed il diametro medio della lesione (lesioni $<1,5 \mathrm{~cm} 68 \%$, tra 1,5 e 5,0 cm 87\%, >5 cm 78\%; $p<0,005$ ).
\end{abstract}

Conclusioni. La diagnosi finale (benignità versus malignità) e le dimensioni della lesione influenzano l'accuratezza diagnostica della metodica: addensamenti polmonari di natura benigna e lesioni con diametro $<1,5 \mathrm{~cm}$ o $>5 \mathrm{~cm}$ sono caratterizzati da livelli minori di accuratezza diagnostica.

Parole chiave Polmone $\bullet$ Biopsia $\bullet$ Tomografia vomputerizzata (TC) $\bullet$ Guida $\bullet$ Accuratezza diagnostica 


\section{Introduction}

Percutaneous transthoracic biopsy is commonly used for the diagnosis of thoracic lesions [1-4]. Computed tomography (CT)-guided needle lung biopsy was first reported by Haaga and Alfidi in 1976 [5], and since then, the technique's excellent efficacy and accuracy and acceptable morbidity and mortality rates $(0.07 \%$, or one death every 1,429 procedures $)$ have been widely demonstrated [6-16]. Diagnostic accuracy is high in both benign (>80\%) and malignant lesions (>90\%) [6-13]. Whether carried out with fine-needle-aspiration cytology (FNAC) or core biopsy (CB), the biopsy provides adequate material for cytological or histological examination and, if necessary, for microbiological evaluation [11-13, 17-21]. FNAC and CB have equivalent diagnostic accuracy in the diagnosis of pulmonary malignancies. CB is more sensitive in defining benign lesions and in characterising diffuse or lymphoproliferative diseases of the lung, where the assessment of the tissue architecture is instrumental to the diagnosis (accuracy $>80 \%$ for CB and $50 \%-70 \%$ for FNAC) [9, 22-25]. Lesions smaller than $1 \mathrm{~cm}$ are easier to sample with FNAC [19, 22, 23].

The reported sensitivity of FNAC varies and is positively affected by the presence of the cytopathologist on site during the biopsy procedure $[26,27]$. Immediate cytological assessment increases the technique's sensitivity and reduces the number of inadequate samples and false negative results [26-28], as the on-site cytopathologist can judge the adequacy, quantity and quality of the sample, suggest the need to repeat the procedure or request $\mathrm{CB}$ with histological assessment $[22,26]$.

Several studies have investigated the factors affecting diagnostic accuracy of CT-guided transthoracic needle biopsies. It is well established that the most important factor is the final diagnosis, as malignant lesions (regardless of histological type) are characterised by greater sensitivity compared with benign masses. As for other variables, Tsukada et al. were the first to demonstrate that diagnostic accuracy declines in proportion to decreasing lesion size [13]. This finding is in contrast with previous studies, which reported a reduction in diagnostic accuracy only for nodules with a small diameter [11, 29-31]. Tsukada et al.'s results were, however, confirmed by Yeow et al., who, in a cohort of 649 subjects, found that diagnostic accuracy was affected by both the final diagnosis and lesion size [20]. Other variables (lesion depth, number of passes, cavitations and necrotic centre, morphology, location, radiologist's experience, needle diameter and presence of pneumothorax and/or bleeding) were not found to be significant [32].

The purpose of this paper is to present our experience with a large cohort of patients and discuss the results achieved in relation to diagnostic accuracy. In particular, we extensively analyse a number of variables (relating to the patient, the lesion or the procedure) in an attempt to correlate them to potential influences on diagnostic accuracy and reach a conclusive judgement on the efficacy of the procedure.

\section{Introduzione}

La biopsia transtoracica percutanea è usualmente utilizzata per la diagnosi di lesioni toraciche [1-4]. L'agobiopsia polmonare TC guidata fu riportata in letteratura per la prima volta nel 1976 da Haaga [5] e da allora numerosi autori ne hanno dimostrato l'estrema efficacia ed accuratezza associate ad un accettabile tasso di morbidità e mortalità (0,07\%, ovvero un decesso ogni 1429 manovre effettuate) [6-16]. L'accuratezza diagnostica risulta elevata sia per la patologia benigna (>80\%), sia per quella maligna (>90\%) [6-13]. Il prelievo, eseguito tramite aspirazione con ago sottile (Fine Needle Aspiration Citology, FNAC) o con ago tranciante (Core Biopsy, $C B$ ), consente di ottenere, rispettivamente, materiale sufficiente per l'esame citologico o istologico ed infine, se necessario, per una valutazione microbiologica [11-13, 17-21]. FNAC e CB presentano accuratezza sovrapponibile nella diagnosi delle neoplasie polmonari maligne. La CB ha maggiore sensibilità nella definizione delle lesioni benigne e nella caratterizzazione delle malattie polmonari diffuse o linfoproliferative, nelle quali la valutazione dell'architettura tissutale è importante per la diagnosi (valori di accuratezza $>80 \%$ per la $C B$ e tra il $50 \%$ ed il 70\% per la FNAC) [9, 22-25]. Le lesioni di dimensioni inferiori al centimetro risultano essere più facilmente campionabili mediante FNAC [19, 22, 23].

La sensibilità della FNAC è variabile nelle casistiche riportate in letteratura ed è positivamente influenzata dalla presenza in sala radiologica del citopatologo al momento del prelievo [26, 27]. La valutazione citologica estemporanea immediata consente di incrementare la sensibilità della metodica, di diminuire il numero dei prelievi inadeguati $e$ dei falsi negativi [26-28]. Il citopatologo, infatti, è in grado di dare indicazione sull'adeguatezza del prelievo, sulla quantità e qualità del materiale campionato, può suggerirne l'eventuale ripetizione o richiedere l'integrazione con l'esame istologico dopo $C B[22,26]$.

Alcuni autori hanno analizzato le variabili che influenzano l'accuratezza diagnostica delle agobiopsie transtoraciche TC guidate. È da tempo assodato come il più importante fattore in questo senso sia la diagnosi finale corretta, dato che le lesioni maligne (indipendentemente dall'istotipo) sono caratterizzate da livelli di sensibilità significativamente maggiori rispetto agli espansi di origine benigna. Considerando altre variabili, Tsukada è stato il primo a dimostrare come la graduale riduzione delle dimensioni della lesione conducesse ad un proporzionale decremento nei valori di accuratezza diagnostica [13]. Questo dato è in contraddizione rispetto alle precedenti segnalazioni, che riportavano una riduzione nell'accuratezza diagnostica solo per $i$ noduli di piccolo diametro [11, 29-31]. I risultati di Tsukada sono però stati successivamente confermati da Yeow che, in una coorte di 649 soggetti, ha riscontrato come sia la diagnosi finale sia le dimensioni della lesione influenzassero il valore di accuratezza [20]. Altre variabili considerate (profondità della lesione, numero di campioni prelevati, cavitazioni e centro necrotico nel contesto della lesione, morfologia, lo- 


\section{Materials and methods}

Study population

Between November 2002 and August 2005, a total of 612 CT-guided transthoracic diagnostic procedures (aspiration biopsy with fine or spinal needle or core biopsy) were carried out on 608 patients. In calculating diagnostic accuracy, repeated biopsies were considered as new procedures. The study population comprised 154 subjects who underwent surgical resection (for whom definitive postoperative histological assessment was available) and nonsurgical patients who had completed at least 12 months of follow-up (454 subjects). The population included 402 men and 206 women, with a mean age of 65.7 years [(median 67; standard deviation (SD) \pm 9.4 years with $95 \%$ confidence interval (CI); range 29-87 years). Part of the procedure was performed in an outpatient setting and part on hospitalised patients.

Our analysis considered all intraparenchymal lesions (central and peripheral), that is, all masses surrounded by aerated lung or in direct contact with hilar structures and/or the pleural surface and whose epicentre was located within the lung (mean lesion size $36.8 \mathrm{~mm}$; median $31.5 \mathrm{~mm}$; $\mathrm{SD} \pm 20.5 \mathrm{~mm}$ with $95 \% \mathrm{CI}$; range $7-103 \mathrm{~mm}$ ).

\section{Biopsy protocol}

None of the patients had a history of bleeding tendency or alterations in blood parameters or coagulation profile. Subjects receiving antiaggregant and/or anticoagulation agents discontinued treatment for 7 days prior to the biopsy. Before the procedure, the radiologist briefly reviewed the patient's history and obtained informed consent. At the time of each biopsy, a previous diagnostic CT scan was available for all patients. Exclusion criteria were lesions $<5 \mathrm{~mm}$ in diameter (calculated as the mean of the long and short axis), significant changes in blood-coagulation profile, contralateral pneumonectomy, patient's inability to maintain a lying position and/or to follow verbal or visual instructions and patient's refusal to accept the potential risks associated with the procedure and sign the informed consent form.

All biopsies were performed according to a standard protocol by the same interventional radiologist (AC) under CT guidance with a spiral dual-detector-row scanner. After positioning the patient on the CT table in prone, supine or lateral decubitus, depending on lesion location, an initial localisation scan was obtained by acquiring the entire mass on 5$\mathrm{mm}$-thick contiguous transverse sections. Then, optimal access (skin entry site and needle path) was defined on CT images, taking care to sample the lesion away from low-density areas, which are often central and indicative of necrosis $[13,17,18]$. After having established the entry site and chosen the type and length of the needle (depending on lesion depth and, whenever possible, the shortest route [33]), the needle entry site was anaesthetised ( $2 \%$ lidocaine), the needle, or the needle guide in the case of $\mathrm{CB}$, positioned and the patient instructed to hold his or her breath.

At this point $\mathrm{CT}$ scans were obtained to visualise the needle tip in relation to the lesion. For masses that were difficult calizzazione, esperienza del radiologo, diametro dell'ago e presenza di pneumotorace elo sanguinamento) non sono risultate significative [32].

Con le sovraesposte premesse, obiettivo di questo studio è presentare la nostra esperienza riferita ad un'ampia coorte di pazienti per discuterne i risultati in rapporto all'accuratezza diagnostica. In particolare verranno estensivamente analizzate alcune variabili (riferite al paziente, alla lesione od alla procedura) nel tentativo di correlarle a potenziali influenze sui valori di accuratezza per formulare un giudizio critico conclusivo sulla efficacia della procedura interventistica.

\section{Materiali e metodi}

Popolazione di studio

In un intervallo temporale compreso tra novembre 2002 ed agosto 2005 sono stati consecutivamente sottoposti a procedura interventistica transtoracica TC guidata per l'accertamento della diagnosi (agoaspirazione transtoracica con ago sottile o con ago spinale o biopsia con ago tranciante) 608 pazienti, per un totale di 612 procedure. La ripetizione della biopsia è stata considerata quale nuova procedura nel calcolo dell'accuratezza diagnostica. La coorte in studio ai fini della formulazione di un giudizio di accuratezza della metodica ha compreso tutti i 154 soggetti resecati (per i quali è risultata disponibile la valutazione istologica definitiva postoperatoria) ed i pazienti non chirurgici che avessero conseguito un follow-up non inferiore a 12 mesi (454 soggetti). La popolazione ha pertanto incluso 402 soggetti di sesso maschile e 206 femminile, con un'età media di 65,7 anni (mediana 67 anni; DS $\pm 9,4$ anni con IC 95\%; intervallo 29-87 anni). I pazienti sono afferiti in parte con proposta di prestazione ambulatoriale ed in parte in regime di ricovero ordinario.

Sono state considerate tutte le lesioni intraparenchimali (centrali e periferiche), ovvero gli espansi circondati da tessuto polmonare areato o a diretto contatto con le strutture ilari elo la superficie pleurica il cui epicentro cadesse all'interno del polmone (dimensione media delle lesioni $36,8 \mathrm{~mm}$; mediana $31,5 \mathrm{~mm} ; D S \pm 20,5 \mathrm{~mm}$ con IC 95\%; intervallo 7-103 mm).

\section{Protocollo bioptico}

Nessun paziente è risultato anamnesticamente positivo per diatesi emorragica o ha presentato alterazioni della crasi ematica e del profilo emocoagulativo. I soggetti in trattamento anti-aggregante elo anticoagulante hanno sospeso tale terapia per un periodo antecedente la biopsia di 7 giorni. Sono stati raccolti dal radiologo un breve raccordo anamnestico ed il consenso informato. Al momento di ogni biopsia, è risultata disponibile una precedente TC diagnostica. I criteri di esclusione da noi adottati sono stati: lesioni con diametro (calcolato sulla media delle dimensioni degli assi maggiore e minore) $<5 \mathrm{~mm}$; alterazioni significative dell'as- 
to target (162/612 procedures, $26.5 \%$ of the total), such as small central nodules or nodules completely covered by bone structures, the biopsy needle was introduced into the soft tissues up to the pleural surface taking care not to cross it. Then, after the precise angle had been checked with successive scans, the needle was finally advanced up to the lesion. Some cases required more than one pleural pass either because the first attempt to reach the lesion failed despite having redirected the needle within the parenchyma, or, in biopsies performed without the aid of the coaxial technique, because the sample was inadequate. In particular, $350 / 612$ procedures $(57.2 \%)$ required a single pleural pass (mean 1.5 passes per procedure; range 1-4). Biopsies were carried out by needle aspiration with a 21-gauge fine needle or a 20gauge spinal needle (with the single needle technique), or by core biopsy with an 18-gauge cutting needle (and coaxial technique).

Our initial approach in pulmonary nodules always uses a Chiba fine needle (especially for small lesions), except in cases of a second attempt after a previous inconclusive procedure. For repeat procedures, we consider the possibility of using a larger needle (spinal) or a cutting needle. By contrast, we always use a cutting needle as a first approach in all cases where a histological sample is preferable to a cytological sample, that is, in cases with a strong clinical suspicion of benign disease or parenchymal lymphoproliferative or sarcomatous lesions (e.g. suspected metastasis in a patient with a previous diagnosis of sarcoma at another location). Finally, a cutting needle is preferred for large masses abutting the visceral pleura. In all cases, we used a biopsy-gun throw length of $3.3 \mathrm{~cm}$.

The presence of the cytopathologist in the radiology suite, essential for aspiration cytology samples, was a characteristic feature of all procedures. The cytopathologist prepared and evaluated the material immediately by using rapid haematoxylin and eosin staining. This made it possible to have an evaluation of material adequacy and an extemporary general indication about the nature of the lesion within minutes of the procedure [26-28]. In the case of inadequate or insufficient samples for cytology or histology, the biopsy procedure was repeated immediately: in particular, 190/612 procedures $(31.0 \%)$ required more than one sampling (mean 1.32 samples per procedure; range $1-4)$.

To assess possible complications (pneumothorax, needletrack bleeding), postprocedural CT scans were acquired 3-5 min after the procedure (time required for the cytopathologist to prepare the slides and judge their adequacy).

Data collection: definition and selection of variables

Multiple discrete or continuous variables, relating to the patient, the lesion or the procedure, were considered. These are discussed below.

\section{Final diagnosis}

The lesions were divided into malignant and benign. For each category, we constructed $2 \times 2$ tables to calculate the levels of accuracy (sensitivity, specificity, positive and nega- setto emo-coagulativo; pneumonectomia controlaterale; impossibilità del paziente a mantenere il decubito clinostatico elo a eseguire comandi verbali o visivi; rifiuto del paziente ad accettare i potenziali rischi correlati e di firma del modulo di consenso informato.

Tutte le biopsie sono state effettuate sotto guida TC mediante un tomografo spirale a doppia corona ed eseguite operativamente dallo stesso radiologo interventista (A.C.) attenendosi ad un protocollo standard. Dopo aver posizionato il paziente sul lettino TC in decubito prono, supino o laterale a seconda della localizzazione della lesione, si è proceduto ad una prima centratura della lesione attraverso l'acquisizione dell'intero espanso su sezioni trasverse contigue di $5 \mathrm{~mm}$ di spessore. Successivamente, sulle immagini TC a monitor si è pianificata la migliore via di accesso (come punto di ingresso cutaneo e tragitto dell'ago) al fine di campionare la lesione avendo cura di evitare regioni di ipodensità, spesso centrali ed indicative di necrosi, nel suo contesto [13, 17, 18]. Dopo aver definito il punto di ingresso dell'ago e scelto la tipologia e la lunghezza dell'ago (a seconda della profondità della lesione e pianificando, ogni qual volta sia stato possibile, il tragitto più breve [33]) si è effettuata un'anestesia locale in corrispondenza del punto cutaneo di ingresso (lidocaina 2\%), quindi si è posizionato l'ago, o l'ago guida per le biopsie trancianti, chiedendo al paziente di mantenere l'apnea.

A questo punto sono state ottenute scansioni TC per localizzare la punta dell'ago rispetto alla lesione. Per gli espansi di difficile centratura (162/612 procedure, $26,5 \%$ del totale) quali piccoli noduli centrali o integralmente "coperti" da strutture ossee, l'ago bioptico è stato introdotto nei tessuti molli sino alla superficie pleurica evitandone accuratamente la trasgressione. Dopo aver controllato con successive scansioni l'esatta angolazione dell'ago, quest'ultimo è stato infine avanzato sino in prossimità della lesione. In alcuni casi si è effettuato più di un passaggio pleurico, dal momento che o la lesione-bersaglio non è stata raggiunta dalla punta dell'ago al primo tentativo nonostante i riorientamenti intraparenchimali dell'ago o, nei prelievi senza ausilio della tecnica coassiale, il materiale è risultato inadeguato e si è ricorsi ad un nuovo prelievo. In particolare, 350/612 procedure $(57,2 \%)$ hanno richiesto un solo passaggio pleurico (media 1.5 passaggi pleurici per procedura; intervallo 1-4). Il prelievo è stato effettuato tramite agoaspirazione con ago sottile 21 gauge $(G)$ o con ago spinale $20 \mathrm{G}$ (con tecnica ad ago singolo), o biopsia con ago tranciante $18 \mathrm{G}$ (utilizzando la tecnica coassiale).

Per i noduli polmonari è sempre preferito da noi un iniziale approccio con ago sottile di Chiba (soprattutto nelle lesioni di piccole dimensioni), tranne nei casi di un secondo tentativo dopo un precedente prelievo non conclusivo. Nell'evenienza della ripetizione iterativa viene considerata la possibilità di utilizzare un ago di calibro maggiore (spinale) od un tranciante. È invece stato utilizzato in prima istanza un ago tranciante in tutti i casi in cui è preferibile ottenere un campione istologico piuttosto che citologico, ovvero nel forte sospetto clinico di patologia benigna o di lesioni linfoproliferative o sarcomatose intraparenchimali (ad esempio sospette metastasi in paziente con pregressa dia- 
tive predictive value, false positive and negative rates and overall accuracy) by correlating the result of the transthoracic biopsy with the final diagnosis. Final diagnoses were based on the surgical outcomes (surgical patients) or the imaging data and clinical-radiological follow-up for a period of at least 12 months (response to first-line chemotherapy or antibiotic treatment designed on the basis of the biopsy; unchanged imaging findings in the absence of treatment). In relation to malignant diagnoses, we considered:

- True positives for malignancy: all cases classified as malignant at transthoracic needle biopsy and confirmed by histology of the surgical specimen; cytohistology of an additional biopsy from a distant metastatic lesion; imaging evidence (radiology or nuclear medicine) of distant metastases; partial or complete response to first-line chemotherapy; clinical course. In surgical cases, we assessed the reliability of the needle biopsy in providing precise characterisation with specific histological type

- A negative finding (benign lesion) was classified as a true negative for malignancy at FNAC or CB when its benign nature was confirmed by subsequent surgery or biopsy or when the lesion appeared stable, smaller or had totally disappeared at follow-up CT (12-month follow-up) in an untreated patient or a patient treated with appropriate antibiotic, but not antineoplastic, therapy [18, 22]

- False positives for malignancy: all cases with a positive biopsy not confirmed by surgery

- False negatives for malignancy: all cases with a negative (benign at FNAC/CB) or indeterminate result (absence of cellular atypia, presence of atypical cells not otherwise specified, presence of nonspecific or granulomatous inflammatory reaction, insufficient material or blood contamination) at transthoracic needle biopsy with positive surgical outcome or disease progression at follow-up imaging.

The quality of each sample obtained by fine-needle transthoracic biopsy was scored from 0 to 3 , according to the following criteria: $0=$ slides containing exclusively blood components (blood contamination) without epithelial cells; $1=$ finding of nonspecific benign cells (inflammatory; type I and II pneumocytes; atypical cells not otherwise specified); $2=$ presence of morphologically malignant cells, without characterisation of histological type or without differentiation between small-cell or non-small-cell cancer; $3=$ slides containing benign or malignant cells with definite histological characterisation. Samples with scores 0, 1 and 2 (when justified by inability to differentiate between small-cell and non-small-cell cancer) were considered nondiagnostic and therefore classed as false negatives in relation to the final diagnosis. Samples with scores of 2 and 3 were considered adequate.

\section{Size}

The dimensions of each lesion were measured on screen using a dedicated programme (electronic callipers), in the two maximum orthogonal axial diameters, on the preliminary localisation scan reconstructed from the raw data with adequate window and level settings for lungs. The arithmetic gnosi di sarcoma in altro distretto). Infine l'ago tranciante è preferito nei grossi espansi a contatto con la pleura viscerale. In tutti i casi è stato utilizzato una lunghezza dello scatto della pistola bioptica pari a $3,3 \mathrm{~cm}$.

La presenza del citopatologo in sala radiologica, essenziale nei prelievi citoaspirativi, ha costituito elemento caratterizzante tutte le procedure. Questi provvedeva all'allestimento ed alla valutazione immediata del materiale ottenuto mediante colorazione rapida con ematossilina-eosina. $\grave{E}$ stato dunque possibile valutare l'adeguatezza del materiale ed ottenere una prima estemporanea e generica indicazione sulla natura della lesione pochi minuti dopo la procedura [26-28]. In caso di materiale inadeguato od insufficiente ad un'analisi citologica od istologica si è provveduto alla immediata ripetizione del prelievo: in particolare 190/612 procedure $(31,0 \%)$ hanno richiesto più di un prelievo (media 1,32 campioni per procedura con intervallo 1-4).

Per valutare l'insorgenza di complicanze (pneumotorace, soffusione emorragica lungo il tragitto dell'ago) sono state acquisite, circa 3-5 minuti dopo il prelievo (nel tempo richiesto dal citopatologo per preparare gli strisci e dare giudizio di idoneità), scansioni TC di controllo.

Raccolta dei dati: definizione e selezione delle variabili

Sono state considerate molteplici variabili, a valore discreto o continuo, riferite al paziente, alla lesione od alla stessa manovra interventistica. Queste vengono di seguito discusse.

\section{Diagnosi definitiva}

Le lesioni sono state suddivise in maligne e benigne. Per entrambe le categorie sono stati calcolati, attraverso la costruzione di tabelle $2 \times 2$, $i$ livelli di accuratezza (sensibilità, specificità, valore predittivo positivo e negativo, proporzione di falsi positivi e negativi, accuratezza globale della metodica) correlando il risultato della biopsia transtoracica con la diagnosi finale. La diagnosi definitiva è stata ottenuta attraverso l'analisi del dato chirurgico (per i pazienti resecati), dei dati di imaging e del follow-up clinico/radiologico per un periodo non inferiore a 12 mesi (risposta a trattamenti chemioterapici di I linea o a trattamenti antibiotici impostati sulla base del risultato bioptico transtoracico; stazionarietà radiologica dei reperti in assenza di terapia). A questo proposito sono stati considerati, in rapporto alle diagnosi maligne:

- veri positivi per malignità $i$ casi classificati maligni all'agobiopsia transtoracica e confermati: dal dato istologico sul pezzo operatorio; dal dato cito-istologico derivante da una ulteriore aggressione bioptica di una lesione metastatica a distanza; dall'evidenza strumentale (indagini radiologiche e di medicina nucleare) di metastasi a distanza; dalla risposta parziale o completa a trattamenti chemioterapici di I linea; dal decorso clinico. Nei casi resecati è stata valutata l'affidabilità dell'agobiopsia transtoracica nel fornire una precisa caratterizzazione con specificità di istotipo;

- un esito negativo (ovvero di natura benigna) è stato classificato vero negativo per malignità alla FNAC o CB in caso di successiva conferma chirurgica o bioptica o se 
means of the measurements obtained for each lesion were then calculated.

\section{Morphology and location}

Lesions were divided into nodules and masses, depending on whether the maximum transverse diameter was $<30 \mathrm{~mm}$ or $\geq 30 \mathrm{~mm}$, respectively. Wedge-shaped infiltrates of fluid or cellular nature, with segmental or lobar distribution associated or otherwise with air bronchogram, were considered consolidations. We recorded data on the presence of single or multiple pulmonary lesions and lobar location specifying possible contact or close proximity to an interlobar fissure, the hilum or major intrapulmonary vessels. The depth of the consolidation was defined as the distance between the entry site on the pleural surface and the proximal edge of the lesion, measured along the needle path on lung window settings [13, 32, 34-36]. This distance corresponds to the linear segment of pulmonary parenchyma traversed by the needle.

\section{Internal characteristics}

We considered solid appearance (if at least $50 \%$ of the surface of the mass was visualised with mediastinal window settings compared with the portion visualised with lung window settings), the presence of excavations (intralesional areas with attenuation levels of air), calcifications and air bronchogram. We also evaluated, visually and with the aid of digital attenuation measurements on regions of interest (ROIs), the baseline density of the lesion to identify possible areas of heterogeneity related to necrosis.

\section{Needle type and calibre}

In all procedures, we used either a single needle (21-gauge Chiba needle; 20-gauge spinal needle; 18-gauge cutting needle with coaxial technique) or, in the event of multiple biopsies, a consecutive combination of different needles. The choice of the type of needle was based on parameters such as lesion size, clinical suspicion (history, clinical and imaging data), operator's preferences and the presence of the cytopathologist. In particular, a Chiba fine needle was used in $470 / 612$ procedures $(76.8 \%)$, a spinal needle in $76(12.4 \%)$, a cutting needle in 35 (5.7\%), a combination of Chiba-spinal needle in $27(4.4 \%)$ and a combination of Chiba-spinal-cutting needle in $4(0.7 \%)$.

\section{Complications}

The occurrence of pneumothorax or subtle parenchymal opacities with ground-glass appearance (due to alveolar haemorrhage) was noted for each procedure.

Statistical analysis

Statistical analysis was conducted with the programme Statistica 6.1 (StatSoft Software for Windows) and aimed at evaluating the accuracy of the procedure. During each ana- presente stabilità, riduzione o totale scomparsa della lesione ai successivi controlli TC (follow-up 12 mesi) in paziente non trattato o sottoposto ad adeguata terapia antibiotica, ma non con farmaci antiblastici [18, 22];

- falsi positivi per malignità i casi risultati positivi alla biopsia transtoracica il cui dato non è stato confermato dall'intervento chirurgico;

- falsi negativi per malignità i pazienti con esito negativo (benigni alla FNAC/CB) od indeterminato (assenza di atipie cellulari, presenza di cellule atipiche non meglio caratterizzabili, presenza di reazione infiammatoria aspecifica o granulomatosa, materiale insufficiente od ematico) all'agobiopsia transtoracica percutanea con riscontro positivo ad una opzione di resezione chirurgica o con progressione di malattia all'imaging seriato di follow-up. Ad ogni campione ottenuto tramite prelievo transtoracico con ago sottile è stato assegnato un punteggio discreto da 0 a 3, al fine di asserirne la qualità, con i seguenti criteri: $0=$ strisci contenenti esclusivamente elementi della serie ematica (prelievo ematico) in assenza di cellule epiteliali; $1=$ riscontro di cellule benigne aspecifiche (infiammatorie; pneumociti di I-II ordine; cellule atipiche non meglio caratterizzabili; $2=$ presenza di cellule morfologicamente maligne, ma per le quali non è possibile definirne il tipo istologico o senza discriminazione tra tumore a piccole cellule e non; $3=$ strisci contenenti cellule benigne o maligne caratterizzabili sotto il profilo anatomo-patologico. I prelievi con punteggio 0, 1 e 2 (se per questi ultimi non è stata possibile una differenziazione tra neoplasia a piccole cellule e non) sono stati considerati non diagnostici e quindi classificati come falsi negativi in rispetto alla diagnosi finale. I prelievi con punteggio 2 e 3 sono stati invece considerati adeguati.

\section{Dimensioni}

Le dimensioni di ogni lesione sono state misurate a monitor mediante programma dedicato (calibro elettronico), nei due diametri assiali ortogonali massimi, sulle scansioni di centratura preliminari ricostruite dai dati grezzi attraverso adeguata finestra e livello per parenchima polmonare. È stata quindi calcolata la media aritmetica relativa alle misurazioni ottenute per ciascuna lesione in esame.

\section{Morfologia e localizzazione}

Le lesioni sono state suddivise in noduli e masse, se caratterizzate da un diametro trasverso massimo $<o \geq 30 \mathrm{~mm}$ rispettivamente. Sono state considerate consolidazioni gli infiltrati cuneiformi, di natura fluida o cellulare, a distribuzione segmentaria o lobare, associati o meno a broncogramma aereo. Sono stati registrati i dati relativi alla presenza di lesioni polmonari singole o multiple, la localizzazione lobare specificando l'eventuale contatto o la stretta vicinanza ad una scissura interlobare, all'ilo o a strutture vascolari intrapolmonari di rilievo. La profondità dell'addensamento è stata considerata quale distanza tra il punto di ingresso della superficie pleurica sino al margine prossimale della lesione, misurata lungo il tragitto dell'ago su finestra per parenchima polmonare [13, 32, 34-36]. Questa distanza corrisponde al seg- 
lytical session, patients were subdivided into two homogeneous groups in terms of discrete dichotomic variables (yes/no) and analysed for the different discrete or continuous variables thought to affect accuracy levels. The groups were subdivided into correct diagnoses and diagnoses that were incorrect or impossible due to sample inadequacy. The variables of the two groups in each category were correlated. Differences between the groups were examined using the nonparametric Mann-Whitney $U$ test or variance analysis according to Kruskal-Wallis, when indicated. Differences between proportions were analysed with Pearson's $\chi^{2}$ test or Student's $t$ test.

Parameters considered significant in determining diagnostic accuracy were further stratified and correlated to accuracy with the aid of contingency graphs and tables. A $p$ value $<0.05$ was taken as significant in all cases.

\section{Results}

In calculating the method's diagnostic accuracy, we considered all 608 patients included in the study:

- There were 154 surgical patients (for whom postoperative surgical evaluation was considered the gold standard against which the interventional technique was compared)

- There were 454 nonsurgical patients who had completed, as at August 2006, an imaging, clinical and treatment-response follow-up of at least 12 months; in these cases the final diagnosis was inferred from the benign or malignant behaviour of the lesion

- We considered 612 procedures; the quality of each of the 612 samples was assigned a discrete score from 0 to 3 at the end of each procedure

- In 435/612 procedures (71.1\%), the needle biopsy recovered benign or malignant cells, allowing specific cytohistological characterisation (score 3). Of these, 52 were benign, 382 were malignant and only one revealed the presence of a hamartochondroma associated with a primary squamous cell carcinoma of the lung

- There were 75/612 samples $(12.2 \%)$ that demonstrated definitely malignant cells (score 2 ), without providing information on histological type. In 71/75 cases (94.6\%), the origin was defined (non-small-cell cancer). Four samples demonstrated the presence of definitely neoplastic cells (probably epithelial) without providing discrimination between small-cell and non-small-cell cancer, which is essential for therapy. The latter cases raise important issues in terms of patient management in that appropriate treatment cannot be planned and the needle biopsy fails to complete the diagnostic process. In addition, the only false positive result in our cohort was encountered among these four cases: a suspected carcinoma not otherwise specified (FNAC) was found at surgery to be an excavated granuloma characterised by severe cellular dysplasia due to previous tuberculous infection

- In 46/612 cases (7.5\%), the sample was scored 1, as 19/46 samples $(41.3 \%)$ demonstrated exclusively normal lung mento lineare di parenchima polmonare trasgredito dall'ago.

\section{Caratteristiche interne}

Sono state considerate l'aspetto solido (se con finestra mediastinica risultava visualizzabile almeno il $50 \%$ della superficie dell'espanso rispetto a quanto visibile con finestra polmonare), la presenza di escavazioni (aree all'interno della lesione con valori di attenuazione propri dell'aria), calcificazioni e broncogramma aereo. È stata inoltre valutata, con criterio visivo ed attraverso l'ausilio della misurazione digitale dei dati di attenuazione mediante ROI, la densità basale della lesione per ricercare eventuali aree di disomogeneità riferibili a necrosi.

Tipo di ago e calibro

Per tutte le procedure si è ricorso all'uso esclusivo di un unico ago (Chiba $21 \mathrm{G}$; spinale $20 \mathrm{G}$; tranciante $18 \mathrm{G}$ con tecnica coassiale) o ad associazione consecutiva di diversi aghi nel caso di prelievi multipli. La scelta di tipologia dell'ago è stata posta secondo alcuni parametri quali le dimensioni della lesione, il sospetto clinico (su basi anamnestiche, obiettive e di imaging) e le preferenze dell'operatore, oltre che la presenza dell'anatomopatologo in sala radiologica. In particolare, l'ago sottile di Chiba ha trovato esclusivo impiego in $470 / 612$ procedure $(76,8 \%)$, l'ago spinale in $76(12,4 \%)$, il tranciante in $35(5,7 \%)$, l'associazione Chibaspinale in $27(4,4 \%)$ e l'associazione Chiba-Spinale-Tranciante in $4(0,7 \%)$.

\section{Complicanze}

La comparsa di pneumotorace o di sfumate opacità parenchimali con aspetto radiologico "a vetro smerigliato" (da impegno alveolare per emorragia) è stata registrata per ogni procedura.

\section{Analisi statistica}

L'analisi statistica è stata condotta con l'utilizzo del programma Statistica 6.1 (StatSoft Software, per Windows) e mirata alla valutazione dell'accuratezza della procedura. I pazienti sono stati, in ogni sessione analitica, suddivisi in due gruppi omogenei per variabili discrete a soluzione dicotomica (si/no) ed analizzati per le diverse variabili, discrete o continue, che si ipotizzava influenzare i livelli di accuratezza: i gruppi sono stati suddivisi tra le diagnosi corrette e le diagnosi non corrette o non possibili a causa dell'inadeguatezza del prelievo agobioptico. Si sono quindi effettuati, tra i due gruppi di ogni categoria, confronti per variabili. Le differenze tra i gruppi sono state esaminate utilizzando i tests non parametrici Mann-Whitney U-test o analisi della varianza secondo Kruskal-Wallis, quando indicati. Le differenze tra le proporzioni sono state analizzate con il test $\chi^{2}$ di Pearson od il test $t$ di Student.

I parametri considerati significativi, nel determinare i livelli di accuratezza diagnostica, sono stati ulteriormente stratificati e correlati all'accuratezza con l'ausilio di grafici 
Table 1 Malignant transthoracic needle biopsy results

\begin{tabular}{ll}
\hline Diagnosis & Number of patients \\
\hline Lung carcinomas & 411 \\
- Adenocarcinoma & 203 \\
- Bronchoalveolar carcinoma (BAC) & 24 \\
- Squamous cell carcinoma & 75 \\
- Adenosquamous carcinoma & 1 \\
- Large cell carcinoma & 7 \\
- Small cell carcinoma (SCLC) & 8 \\
- Non-small-cell carcinoma (NSCLC) (not further specified) & 72 \\
- Malignant-cell-type carcinoma (not otherwise specified) & 4 \\
- Carcinoid & 17 \\
Nonepithelial lung tumours & 7 \\
- Lymphoma (BALT) & 5 \\
- Malignant schwannoma & 1 \\
- Malignant histiocytoma & 1 \\
Metastases & 40 \\
Total & 458 \\
\hline
\end{tabular}

cells (type I and II pneumocytes), 14/46 (30.4\%) contained inflammatory cells without significant atypia and $13 / 46(28.3 \%)$ contained atypical cells not otherwise specified and not classifiable as definitely malignant. In 16 of these 46 samples (34.7\% of samples with score 1 ; $2.6 \%$ of all procedures), the lesions were found to be malignant. The discordance between the biopsy result and the final diagnosis is due to sampling errors, with sampling of surrounding healthy lung parenchyma or perilesional reactive inflammatory tissue

- There were 56/612 samples $(9.1 \%)$ scored 0 owing to sample inadequacy (blood contamination) and which were therefore classed as nondiagnostic. In 35/56 samples ( $60.7 \%$ of samples with a score of 0$)$, the lesion was subsequently found to be malignant.

A final diagnosis based on the criteria previously described could be obtained for all 612 procedures: $17.0 \%$ (104/612) of lesions were found to be benign, whereas $83.0 \%$ (508/612) were malignant. Transthoracic needle biopsy was diagnostic in 511 cases out of $612(83.5 \%$; samples scored 2 and 3 ), whereas in 101 procedures $(16.5 \%$, samples scored 0 and 1), no reliable judgement could be made. Among the 511 cases diagnosed with biopsy, 459 (89.8\%) were malignant and $52(10.2 \%)$ benign. The 458 cases positive for malignancy, with subsequent confirmation (one malignant case at biopsy was subsequently found to be a false positive) comprised 411 primary lung cancers, seven nonepithelial neoplasms and 40 metastatic tumours with secondary localisation to the lung (Table 1).

Of these 458 patients, $46(7.6 \%)$ had a history of neoplastic disease at another location. Of these 46, the metastatic origin of the lung lesion was demonstrated in 40, whereas in the remaining six cases, the primary nature of the lung nodule was demonstrated with the aid of immunocytochemistry and comparison with cytology and/or histology of the extrapulmonary neoplasm, when available.

Among the 459 cases of malignancy diagnosed at biopsy, o tabelle di contingenza. In tutti i casi è stato considerato significativo un valore di $p<0,05$.

\section{Risultati}

Per calcolare l'accuratezza diagnostica della metodica sono stati inclusi nello studio 608 pazienti:

- Centocinquantaquattro sono i soggetti sottoposti ad intervento chirurgico (per i quali è disponibile l'esame istologico post-operatorio, considerato il "gold standard" di raffronto con la metodica interventistica).

- Quattrocentocinquantaquattro sono, invece, $i$ pazienti non chirurgici che presentano ad agosto 2006 un followup di imaging, clinico e di risposta terapeutica non inferiore a 12 mesi; in base al comportamento benigno o maligno della lesione in esame è stata, quindi, dedotta la diagnosi finale.

Complessivamente sono state considerate 612 procedure. Per ciascuno dei 612 campioni ottenuti, a conclusione di ogni procedura è stato attribuito un punteggio discreto da 0 a 3 per asserirne la qualità:

- In 435/612 procedure (71,1\% dei casi) si sono ottenute, dal prelievo agobioptico, cellule benigne o maligne che hanno permesso una precisa caratterizzazione citoistologica della lesione (punteggio 3). Di queste 52 sono risultate benigne, 382 di natura maligna, mentre in 1 solo caso si è registrata la presenza di un amartocondroma associato ad un carcinoma polmonare primitivo del tipo squamocellulare;

- In 75/612 prelievi (12,2\% dei casi) sono state riscontrate cellule di sicura origine maligna (punteggio 2), ma non ̀̀ stato possibile trarre conclusioni sull'istotipo. In 71/75 casi $(94,6 \%)$ è stata definita l'origine (tumori non a piccole cellule). In 4 prelievi si è documentata la presenza di sicure cellule neoplastiche (verosimilmente epiteliali) in 
Tabella 1 Classificazione delle diagnosi citoistologiche positive per malignità

\begin{tabular}{ll}
\hline Diagnosi & Numero di pazienti \\
\hline Tumori primitivi polmonari epiteliali & 411 \\
- Adenocarcinoma & 203 \\
- Carcinoma bronchiolo-alveolare (BAC) & 24 \\
- Carcinoma a cellule squamose & 75 \\
- Carcinoma adenosquamoso & 1 \\
- Carcinoma a grandi cellule & 7 \\
- Carcinoma a piccole cellule (SCLC) & 8 \\
- Carcinoma non a piccole cellule (NSCLC) & 72 \\
- Carcinoma (non possibile distinzione SCLC/NSCLC) & 4 \\
- Carcinoide & 17 \\
Neoplasie primitive polmonari non epiteliali & 7 \\
- Linfoma (BALT) & 5 \\
- Schwannoma maligno & 1 \\
- Istiocitoma maligno & 1 \\
Metastasi & 4 \\
Totale & 40
\end{tabular}

one case only was not confirmed by the final diagnosis and was therefore the only false positive case for malignancy. In contrast, 50 procedures were false negative for malignancy (negative result at biopsy, with malignant cells detected at repeat biopsy, surgery or follow-up). Table 2 shows the results obtained, in terms of accuracy, in the correct diagnosis of malignant lesions. Table 3 summarises the cytological diagnoses of the 52 cases that were negative for malignancy at biopsy.

If we consider only benign lesions at final diagnosis assenza di una suddivisione, critica ai fini terapeutici, in tumore a piccole cellule e non. Questi ultimi casi pongono importanti problematiche in termini di gestione del paziente per il fatto che non si può pianificare il corretto iter terapeutico, impedendo in questo modo all'agobiopsia di porsi a termine dell'iter diagnostico. Inoltre, tra questi 4 casi si è riscontrato l'unico risultato bioptico falso positivo dell'intera coorte: un sospetto carcinoma di non più precisa caratterizzazione (FNAC) si è poi dimostrato essere, dopo resezione chirurgica, una granulomatosi esca-

Table 2 Results of 612 computed-tomography-guided transthoracic needle biopsies

\begin{tabular}{llll}
\hline Biopsy diagnosis & $\begin{array}{l}\text { Final diagnosis } \\
\text { Malignant }\end{array}$ & Benign & Total \\
\hline Malignant & 458 & 1 & 459 \\
Benign/inadequate & 50 & $103(52 / 51)$ & 153 \\
Total & 508 & 104 & 612 \\
\hline
\end{tabular}

${ }^{\text {a }}$ Final diagnoses are based on the retrospective analysis of the outcome of surgery, repeated biopsy, imaging, and clinical follow-up for at least 12 months. Malignant pulmonary lesions: sensitivity $90.2 \%$ (458/508), specificity $99.0 \%$ (103/104), positive predictive value $99.8 \%(458 / 459)$, negative predictive value $67.3 \%$ (103/153), false positive rate $0.22 \%$ (1/459), false negative rate $10.9 \%(50 / 508)$, accuracy $91.7 \%$ [(458+103)/612], overall diagnostic accuracy $83.3 \%$ [(458+52)/612] (for all lesions, benign and malignant)

Tabella 2 Risultati di 612 procedure agobioptiche polmonari

\begin{tabular}{llll}
\hline Diagnosi bioptica & $\begin{array}{l}\text { Diagnosifinale } \\
\text { Maligno }\end{array}$ & Benigno & Totale \\
\hline Maligno & 458 & 1 & 459 \\
Benigno-inadeguato & 50 & $103(52 / 51)$ & 153 \\
Totale & 508 & 104 & 612 \\
\hline
\end{tabular}

${ }^{a}$ La diagnosi finale deriva dall'analisi retrospettiva dei risultati della chirurgia, di un'eventuale successiva agobiopsia transtoracica e dall'esito del followup clinico/radiologico pari ad un periodo non inferiore ai 12 mesi. Espansi polmonari di natura maligna: Sensibilità 90,2\% (458/508), Specificità 99,0\% (103/104), Valore predittivo positivo 99,8\% (458/459), Valore predittivo negativo 67,3\% (103/153), Ratio di falsi positivi 0,22\% (1/459), Ratio di falsi negativi 10,9\% (50/508), Accuratezza 91,7\% ([458+103]/612), Accuratezza diagnostica globale 83,3\% ([458+52]/612) (per tutte le lesioni, benigne e maligne) 
Table 3 Benign transthoracic needle biopsy results

\begin{tabular}{ll}
\hline Diagnosis & Number of patients \\
\hline Benign tumours & 8 \\
- Hamartochondroma & 3 \\
- Schwannoma & 3 \\
- Cystoadenoma & 2 \\
Inflammatory - infectious & 31 \\
- Nonspecific inflammation & 9 \\
- Granulomatous inflammation & 13 \\
- Specific inflammation: & \\
- Tuberculosis & 5 \\
- Fungal infection & 2 \\
- pneumoocystis carinii & 1 \\
- Eosinophilic pneumonia & 1 \\
Inflammatory - not infectious & 12 \\
- Fibrosis/sclerohyalinosis & 9 \\
- Granulomatosis: & \\
Rheumatoid arthritis & 1 \\
Epithelioid-giant cell & 1 \\
- Round atelectasis & 1 \\
Miscellaneous & 1 \\
- Sclerosing haemangioma & 1 \\
Total & 52 \\
&
\end{tabular}

Tabella 3 Classificazione delle diagnosi citoistologiche negative per malignità

\begin{tabular}{ll}
\hline Diagnosi & Numero di Pazienti \\
\hline Neoplasie benigne & 8 \\
- Amartocondroma & 3 \\
- Schwannoma & 3 \\
- Cistoadenoma & 2 \\
Infiammatoria infettiva & 31 \\
- Flogosi florida aspecifica & 9 \\
- Flogosi granulomatosa & 13 \\
- Flogosi ad agente eziologico noto: & \\
- Tubercolosi & 5 \\
- Miceti & 2 \\
- Pneumocystis cariniii & 1 \\
Polmonite eosinofila & 1 \\
Infiammatoria non infettiva & 12 \\
- Fibrosi/scleroialinosi & 9 \\
- Granulomi: & \\
Artrite reumatoide & 1 \\
Epitelioide-gigantocellulare & 1 \\
- Atelettasia rotonda & 1 \\
Altro & 1 \\
- Emangioma sclerosante & 1 \\
Totale & 52 \\
\hline &
\end{tabular}

(104/612; 17\%), needle biopsy allowed a certain judgement of benignity, with a specific diagnosis in only 52 cases, that is, in $50 \%$ of all benign lesions. Conversely, in 51 cases, the benign nature of the lesion could not be defined because of sample inadequacy (30 samples scored 1 and 21 scored 0 ).

With regard to malignant lesions, $99.8 \%$ of malignancies at vata caratterizzata da severa displasia cellulare in relazione alla pregressa infezione tubercolare;

- In 46/612 casi (7,5\%) è stato attribuito, al campione prelevato, un punteggio pari a 1, dal momento che in 19/46 casi $(41,3 \%)$ si sono riscontrate esclusivamente cellule normali proprie del tessuto polmonare (pneumociti di I $e$ II ordine), in 14/46 (30,4\%) cellule flogistiche in assenza di significative atipie ed in 13/46 (28,3\%) cellule atipiche non ulteriormente caratterizzabili, ma neanche classificabili come sicuramente maligne. In 16 di questi 46 prelievi $(34,7 \%$ dei prelievi a punteggio 1; 2,6\% sul totale delle procedure) le lesioni campionate sono poi risultate di natura maligna. La discordanza tra risultato bioptico e diagnosi finale è dovuta ad errori di campionamento, per prelievo di parenchima polmonare sano limitrofo o di tessuto flogistico reattivo perilesionale;

- Infine 56/612 prelievi (9,1\%) hanno ottenuto un punteggio pari a zero a causa dell'inadeguatezza del materiale analizzato dall'anatomopatologo (campioni ematici) e sono quindi stati classificati come non diagnostici. In 35/56 prelievi $(60,7 \%$ dei campioni a punteggio 0) la lesione è poi risultata maligna.

Per tutte le 612 procedure è stato possibile ottenere una diagnosi finale con i criteri già ampiamente descritti: il $17,0 \%$ (104/612) delle lesioni è risultato di natura benigna, mentre lo 83,0\% (508/612) maligna. L'agobiopsia transtoracica percutanea ha conseguito un risultato diagnostico in 511 casi su 612 (83,5\%, prelievi a punteggio 2 e 3), mentre in 101 procedure $(16,5 \%$, prelievi a punteggio 0 e 1) non è stato possibile fornire un giudizio affidabile. Tra i 511 casi diagnosticati alla biopsia, 459 (89,8\%) sono risultati maligni e 52 (10,2\%) benigni. I 458 casi positivi per malignità, con conferma successiva (un caso maligno alla biopsia è poi risultato un falso positivo) hanno compreso 411 carcinomi polmonari primitivi, 7 neoplasie non epiteliali e 40 tumori metastatici con localizzazione secondaria al polmone (Tabella 1).

Di questi 458 pazienti, 46 (7,6\%) presentavano un precedente anamnestico di malattia neoplastica in altra sede. Tra questi ultimi, in 40 si è dimostrata l'origine metastatica della lesione polmonare, mentre nei restanti 6 casi è stato possibile definire la natura primitiva del nodo polmonare attraverso l'ausilio della immunocitochimica ed il confronto, quando disponibile, con i reperti citologici elo istologici del tumore extrapolmonare.

Tra i 459 riscontri risultati maligni all'agobiopsia, solo in un caso la diagnosi definitiva non ha confermato il dato configurando quindi la presenza di un unico falso positivo per malignità. Si sono invece registrate 50 procedure false negative per malignità (risultato negativo per cellule neoplastiche con esito maligno alla ripetizione della procedura, all'intervento chirurgico od al follow-up). In Tabella 2 vengono riportati i risultati conseguiti, in termini di affidabilità della metodica, sulla corretta diagnosi delle lesioni maligne. La Tabella 3 riassume le diagnosi citologiche nei 52 casi risultati negativi per malignità all'agobiopsia.

Analizzando le sole lesioni benigne alla diagnosi finale (104/612, 17\%), l'agobiopsia ha permesso di conseguire un sicuro giudizio di benignità con diagnosi specifica in soli 52 
needle biopsy were confirmed (458/459; positive predictive value for malignancy), whereas $67.3 \%$ of samples without neoplastic cells (samples classified as benign or inadequate) were found to be benign (103/153; negative predictive value for malignancy). A specific judgement of benignity of the biopsy sample could, however, be made in only $34 \%$ of samples, characterised by the definite absence of neoplastic cells (52/153) (Table 2). Sensitivity and specificity for a diagnosis of malignancy were $91 \%$ and $99 \%$, respectively, with a minority of false positive $(0.22 \%)$ and $11 \%$ false negative results. Overall accuracy was $84 \%$ (510/612 lesions correctly characterised at needle biopsy) (Table 2). This value increased to $88.2 \%$ (540/612) if, among the correct biopsy diagnoses, we included the 30 samples with a score of 1 that were subsequently found to be benign (i.e. samples with negative biopsy for neoplastic cells but without a specific diagnosis). Table 4 lists all the variables that we hypothesised would affect the accuracy of the method: the only variables significantly associated with lower levels of diagnostic accuracy were the final diagnosis (benign vs. malignant) and lesion size. Diagnostic accuracy for benign and malignant lesions was $67 \%$ and $92 \%$, respectively (Pearson's $\chi^{2}$ test, $p<0.001$ ).

Figure 1a shows the relationship between mean lesion size and number of observations for all lesions examined and for lesions with (Fig. 1b) and without (Fig. 1c) central necrosis. With regard to lesion size, we observed a substantial reduction in diagnostic accuracy in nodules with a mean diameter $<1.5 \mathrm{~cm}(67 \%$ correct diagnoses among lesions $<1.5$ $\mathrm{cm})$ and in masses $>5.0 \mathrm{~cm}$ (78\% correct diagnoses) (Pearson's $\chi^{2}$ test, $p<0.005$ ) (Fig. 2). The paradoxical lower accuracy in large masses is due to the higher rate of central necrosis among large lesions (Fig. 3; Table 5). This accounts for the higher rate of sample inadequacy among specimens from masses $>5.0 \mathrm{~cm}$ with respect to those between $1.5 \mathrm{~cm}$ and $5.0 \mathrm{~cm}$ as a result of sampling at the level of small necrotic foci not detectable as definite low-density areas. Table 5 shows a statistically significant difference in size between lesions without (mean $34.0 \pm 18.6 \mathrm{~cm}$ ) and with (mean $57.7 \pm 18.5 \mathrm{~cm}$ ) central necrosis (Student's $t$ test, $p<0.001$; Fig. 4). The incidence of necrosis was higher for masses $>5.0$ $\mathrm{cm}(30.2 \%)$ compared with lesions $5.0 \mathrm{~cm}(5.9 \%)$ (Pearson's $\chi^{2}$ test, $\left.p<0.001\right)$. Finally, Table 4 demonstrates that lesion depth (the portion of aerated lung traversed by the needle), morphology and lobar location; the presence of calcification, cavitation and necrotic centre; and the occurrence of complications (pneumothorax and bleeding) have no influence on the diagnostic accuracy of transthoracic CT-guided needle biopsy.

\section{Discussion}

With the use of percutaneous transthoracic needle biopsy, and in particular of FNAC, as an initial minimally invasive procedure for evaluating the nature of pulmonary lesions, this study obtained an overall diagnostic accuracy of $84 \%$, with levels of $92 \%$ and $67 \%$ for malignant and benign lesions, respectively. The technique's sensitivity was $90 \%$ casi ovvero nel 50\% dei casi sul totale delle lesioni di natura benigna. In 51 lesioni benigne non è invece stato possibile stabilirne la natura a causa dell'inadeguatezza del prelievo (30 prelievi a punteggio 1 e 21 prelievi a punteggio 0 ).

Riferendosi agli addensamenti polmonari di natura maligna, il 99,8\% delle lesioni considerate maligne all'agobiopsia è poi stata confermata $(458 / 459$, valore predittivo positivo per malignità), mentre il 67,3\% dei prelievi con assenza di cellule tumorali (prelievi classificati come benigni, od inadeguati) è risultato benigno (103/153, valore predittivo negativo per malignità). È stato comunque possibile dare un giudizio specifico di benignità del prelievo agobioptico solo nel $34 \%$ dei campioni, caratterizzati dalla sicura assenza di cellule tumorali (52/153) (Tabella 2). La sensibilità e la specificità per la diagnosi di malignità sono risultate del $91 \%$ e 99\% rispettivamente, con una proporzione di falsi positivi trascurabile $(0,22 \%)$ ed una proporzione di falsi negativi dell'11\%. L'accuratezza globale è stata pari all'84\% (510/612 lesioni correttamente caratterizzate alla agobiopsia transtoracica) (Tabella 2). Questo valore raggiunge l'88,2\% (540/612) se, tra le diagnosi agobioptiche corrette, si includono i 30 prelievi a punteggio 1 poi risultati benigni (ovvero reperti considerati all'agobiopsia negativi per cellule neoplastiche in assenza di una specifica diagnosi). In Tabella 4 è riassunto l'insieme di variabili che si è supposto esercitare una influenza sui livelli di accuratezza della metodica: le uniche variabili associate con significatività statistica ad una riduzione dei livelli di accuratezza diagnostica sono risultate la discrimante della diagnosi finale (categoria benigno versus maligno) e le dimensioni della lesione. I valori di accuratez$z$ a diagnostica per lesioni benigne e maligne sono stati del $67 \%$ e $92 \%$ rispettivamente (test $\chi^{2}$ di Pearson, $p<0,001$ ).

La Figura la mostra la distribuzione diametro medio su casi osservati, rispettivamente per tutti i casi e per lesioni con (Fig. 1b) e senza (Fig. Ic) necrosi centrale. Per quanto riguarda il diametro delle lesioni si è ottenuta una sensibile riduzione dei valori di accuratezza diagnostica per noduli con diametro medio $<1,5 \mathrm{~cm}$ (diagnosi corrette $67 \%$ sul totale delle lesioni $<1,5 \mathrm{~cm}$ ) e per masse $>5,0 \mathrm{~cm}$ (diagnosi corrette $78 \%$ ) (test $\chi^{2}$ di Pearson, $p<0,005$ ) (Fig. 2). La paradossale riduzione di accuratezza per le grosse masse è dovuta alla maggior correlazione di queste ultime con la presenza di necrosi centrale (Fig. 3; Tabella 5). Questo aspetto rende ragione della maggior proporzione di inadeguatezza dei campioni prelevati in masse $>5,0 \mathrm{~cm}$ rispetto a lesioni tra 1,5 e $5,0 \mathrm{~cm}$, per preferenziale campionamento a livello di limitati foci necrotici, non evidenziabili come franche ipodensità.

La Tabella 5 mostra una differenza statisticamente significativa di dimensioni della lesione in assenza (media $34,0 \pm 18,6 \mathrm{~mm}$ ) e presenza (media $57,7 \pm 18,5 \mathrm{~mm}$ ) di necrosi centrale (test $t$ di Student, $p<0,001)$ (Fig. 4). L'incidenza di necrosi è risultata maggiore per le masse $>5,0 \mathrm{~cm}$ $(30,2 \%)$ rispetto alle lesioni $\leq 5,0 \mathrm{~cm}(5,9 \%)$ (test $\chi^{2}$ di Pearson, $p<0,001)$. La Tabella 4 dimostra, infine, come la profondità della lesione (ovvero la quota di parenchima polmonare aerato attraversata dall'ago), la sua morfologia e localizzazione lobare, la presenza di calcificazioni, cavitazioni e centro necrotico, oltrechè l'occorrenza di complicanze (pneumotorace e sanguinamento) non esercitino alcuna 
Table 4 Characteristics of correct and incorrect biopsy results by final diagnoses in 612 transthoracic needle biopsies

\begin{tabular}{llll}
\hline Characteristic & $\mathrm{N}^{\mathrm{a}}(612)$ & $\begin{array}{l}\text { Final diagnosis } \\
\text { Incorrect } \mathrm{n}=102(\%)\end{array}$ & Correct $\mathrm{n}=510(\%)$ \\
\hline $\begin{array}{l}\text { Final diagnosis } \\
- \text { Benign }\end{array}$ & & & \\
- Malignant & 104 & $52(50.0)$ & $52(50.0)$ \\
Lesion size & $50(9.8)$ & $458(90.2)$ \\
$-<1.5 \mathrm{~cm}$ & 508 & $15(33.3)$ & $30(66.6)$ \\
$-1.5-5.0 \mathrm{~cm}$ & & $53(12.7)$ & $362(87.3)$ \\
$->5.0 \mathrm{~cm}$ & 45 & $34(22.4)$ & $118(77.6)$ \\
Lesion depth & 415 & & - \\
Lesion cavity & 152 & & \\
Necrotic centre & & - & \\
Lesion calcifications & & & \\
Lesion morphology & & & \\
Lesion location & & & \\
Pneumothorax & & & \\
Bleeding & & & \\
\hline
\end{tabular}

Values in brachets are referred in \%. ${ }^{\mathrm{a} N u m b e r}$ of procedures; ${ }^{\mathrm{b}}$ Pearson's $\chi^{2}$ test for categoric variables; ${ }^{\mathrm{c}}$ Average lesion diameter in two axial planes; $N S$, not significant

Tabella 4 Correlazione per variabili, con la diagnosi finale, di risultati corretti ed errati od indeterminati all'agobiopsia transtoracica

\begin{tabular}{llll}
\hline Variabile & $N^{a}(612)$ & $\begin{array}{l}\text { Diagnosi finale } \\
\text { Errata o indeterminata } \\
N=102\end{array}$ & $\begin{array}{l}\text { Corretta } \\
N=510\end{array}$ \\
\hline $\begin{array}{l}\text { Diagnosi finale } \\
\text { - Benigna }\end{array}$ & 104 & $52(50,0)$ & $52(50,0)$ \\
- Maligna & 508 & $50(9,8)$ & $458(90,2)$ \\
Dimensioni lesione & & $30(66,6)$ \\
$-<1,5$ cm & 45 & $15(33,3)$ & $362(87,3)$ \\
$-1,5-5,0$ cm & 415 & $53(12,7)$ & $118(77,6)$ \\
$->5,0$ cm & 152 & $34(22,4)$ & \\
$\begin{array}{l}\text { Profondità lesione } \\
\text { Cavitazioni } \\
\text { Centro necrotico }\end{array}$ & & & \\
Calcificazioni & - & - & \\
Morfologia & & & \\
$\begin{array}{l}\text { Localizzazione } \\
\text { Pneumotorace } \\
\text { Sanguinamento }\end{array}$ & & & \\
\hline
\end{tabular}

I valori in parentesi sono riferiti in \%. ${ }^{a}$ Grandezza del campione; ${ }^{b}$ Test $\chi^{2}$ di Pearson per variabili categoriche; ${ }^{c}$ Considerata quale dimensione media tra i due assi (maggiore e minore) ortogonali della lesione; NS, non significativo.

(with 99\% specificity) for malignant lesions but $50 \%$ (with $100 \%$ specificity) for benign lesions. These findings demonstrate that FNAC is inferior to $\mathrm{CB}$ for the diagnostic evaluation of benign lesions $[20,24]$. However, they are also dependent on the severity with which sample adequacy is judged: a sample without neoplastic cells should not be considered negative for malignancy (consider sampling errors, for example) unless they provide a precise and specific diagnosis of benignity ( $100 \%$ specificity is desirable in benign lesions). Many studies [13, 29, 32, 37, 38] have reported substantially lower levels of diagnostic accuracy for benign lung lesions (range 52\%-91\%) compared with malignant lesions influenza sui valori di accuratezza diagnostica dell'agobiopsia transtoracica TC guidata.

\section{Discussione}

Attraverso l'utilizzo dell'agobiospia transtoracica percutanea, ed in particolar modo della FNAC, quale iniziale procedura mini-invasiva nella valutazione di natura degli addensamenti polmonari si è ottenuta, in questo studio, un'accuratezza diagnostica globale dell'84\% con valori di accu- 


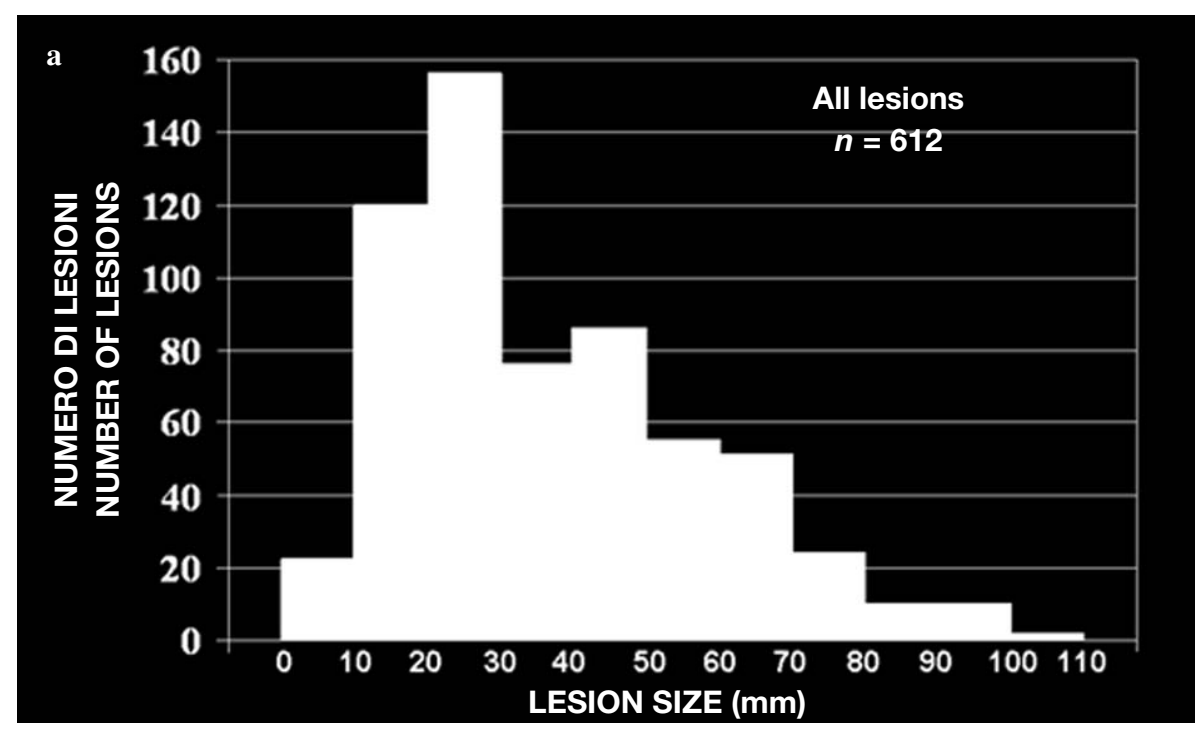

Fig. 1a-c Relationship between mean lesion size and number of observations for the entire group of lesions (a) and in regard to the presence (b) or the absence (c) of a necrotic centre. Diagrams show that number of observations is higher for lesions larger than $40 \mathrm{~cm}$ in the presence of a necrotic centre (b), but higher for nodules smaller than $30 \mathrm{~cm}$ in the absence of a necrotic centre (c).

Fig. 1a-c Correlazione tra diametro medio della lesione e numero di casi per tutte le lesioni $(\boldsymbol{a}) e$ suddividendo queste ultime per presenza $(\boldsymbol{b})$ od assenza (c) di centro necrotico. I grafici pongono in evidenza come il numero di osservazioni, in presenza di centro necrotico, sia maggiore per addensamenti superiori a $40 \mathrm{~cm}$, mentre sia maggiore, in assenza di centro necrotico, per lesioni al di sotto dei $30 \mathrm{~cm}$.
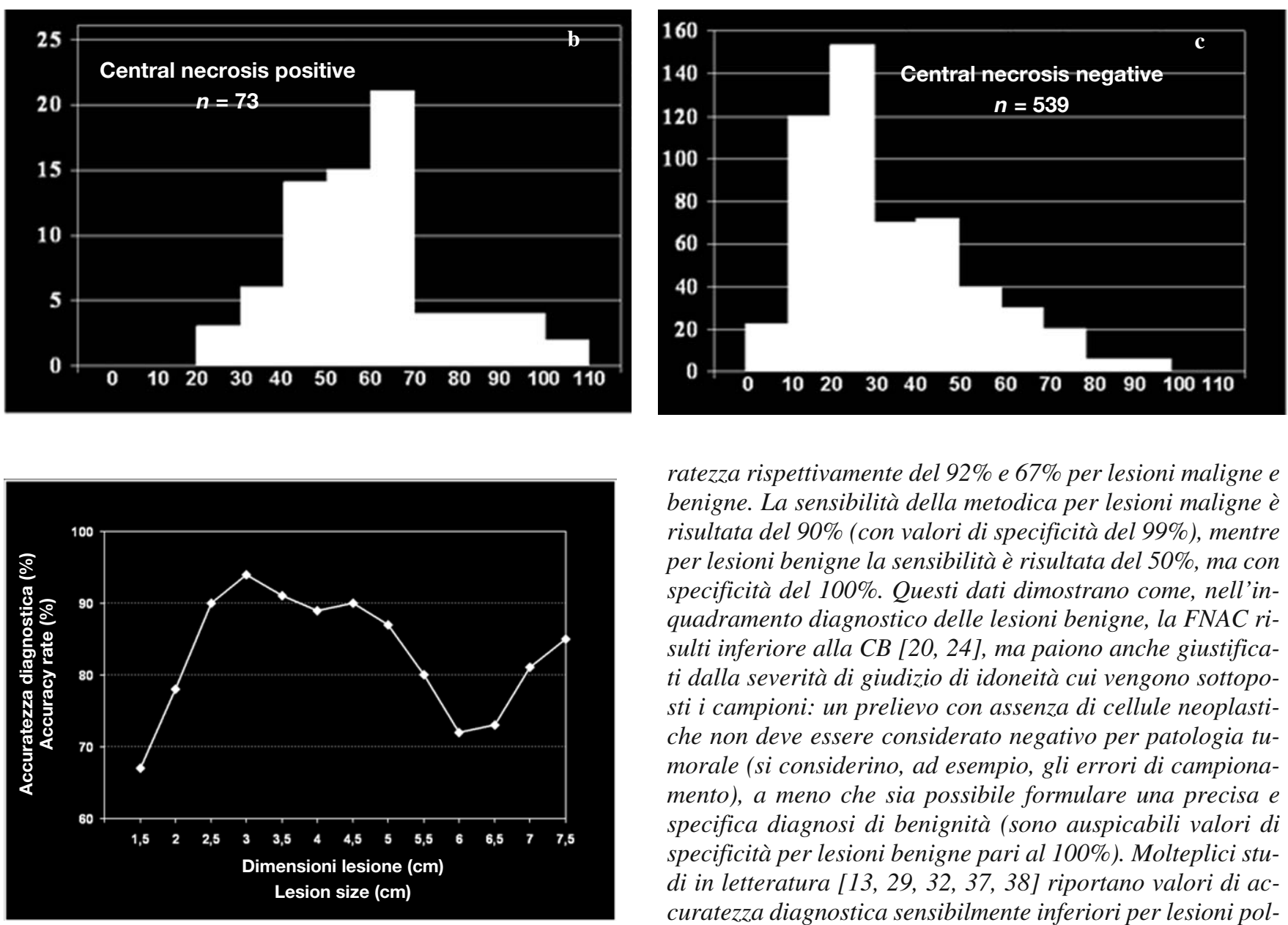

ratezza rispettivamente del $92 \%$ e $67 \%$ per lesioni maligne e benigne. La sensibilità della metodica per lesioni maligne è risultata del $90 \%$ (con valori di specificità del 99\%), mentre per lesioni benigne la sensibilità è risultata del 50\%, ma con specificità del 100\%. Questi dati dimostrano come, nell'inquadramento diagnostico delle lesioni benigne, la FNAC risulti inferiore alla CB [20, 24], ma paiono anche giustificati dalla severità di giudizio di idoneità cui vengono sottoposti i campioni: un prelievo con assenza di cellule neoplastiche non deve essere considerato negativo per patologia tumorale (si considerino, ad esempio, gli errori di campionamento), a meno che sia possibile formulare una precisa $e$ specifica diagnosi di benignità (sono auspicabili valori di specificità per lesioni benigne pari al 100\%). Molteplici studi in letteratura [13, 29, 32, 37, 38] riportano valori di accuratezza diagnostica sensibilmente inferiori per lesioni polmonari benigne (con intervallo compreso tra il 52\% ed il 91\%) se paragonate a lesioni maligne (intervallo compreso tra l'86\% ed il 100\%), sia nel prelievo aspirativo sia tranciante; inoltre, considerando esclusivamente gli addensamenti benigni, la CB presenta valori di accuratezza e sensibilità significativamente maggiori rispetto alla FNAC (accuratezza superiore all' $80 \%$ versus 50\%-70\%) [9, 22-25]. I livelli di accuratezza e sensibilità riportati dal nostro studio sono in linea con i riscontri FNAC della letteratura, ma non 
Table 5 Correlation of lesion size with incidence of necrosis in lung lesions

\begin{tabular}{llll}
\hline Lesion size $^{\mathrm{a}}$ & $\begin{array}{l}\text { Necrotic centre } \\
\text { Negative } \mathrm{n}=539\end{array}$ & Positive $\mathrm{n}=73$ & $P$ value \\
\hline$\leq 5.0 \mathrm{~cm}(\mathrm{n}=460)$ & $433(94.1 \%)$ & $27(5.9 \%)$ & $<0.001^{\mathrm{b}}$ \\
$>5.0 \mathrm{~cm}(\mathrm{n}=152)$ & $106(69.8 \%)$ & $46(30.2 \%)$ & $<0.001^{\mathrm{c}}$ \\
Mean $\pm \mathrm{SD}(\mathrm{mm})$ & $34.0 \pm 18.6$ & $57.7 \pm 18.5$ & \\
\hline
\end{tabular}

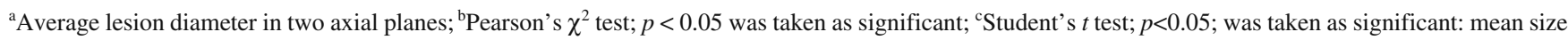
of lesions with $(57.7 \mathrm{~mm})$ and without $(34.0 \mathrm{~mm})$ necrosis differs significantly.

Tabella 5 Correlazione tra diametro medio delle lesioni ed incidenza di necrosi negli espansi polmonari

\begin{tabular}{llll}
\hline Diametro lesione* & $\begin{array}{l}\text { Centro necrotico } \\
\text { Negativo } n=539\end{array}$ & $p$ & Positivo $n=73$ \\
\hline$\leq 5,0 \mathrm{~cm}(n=460)$ & $433(94,1 \%)$ & $27(5,9 \%)$ & $<0,001^{b}$ \\
$>5,0 \mathrm{~cm}(n=152)$ & $106(69,8 \%)$ & $46(30,2 \%)$ & $<0,001^{c}$ \\
Media $\pm D S(\mathrm{~cm})$ & $34,0 \pm 18,6$ & $57,7 \pm 18,5$ & \\
\hline
\end{tabular}

${ }^{a}$ Considerata quale dimensione media tra $i$ due assi (maggiore e minore) ortogonali della lesione. ${ }^{b}$ Test $\chi^{2}$ di Pearson, p<0,05 considerata significativa. ${ }^{c}$ Test $t$ di Student (per campioni indipendenti e per gruppi), $p<0,05$ considerata significativa: il diametro medio delle lesioni con $(57,7 \mathrm{~mm})$ e senza $(34,0 \mathrm{~mm})$ necrosi differisce con significatività statistica.

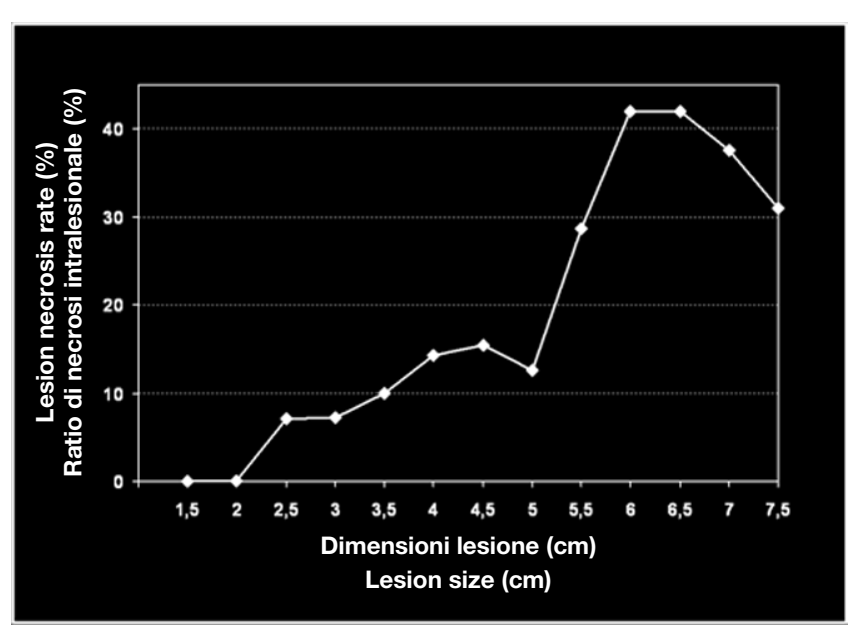

Fig. 3 Relationship between lesion size and lesion necrosis rate: the diagram shows that incidence of necrosis becomes proportionately higher with increasing lesion size, the highest necrosis rate being encountered in lesions larger than $6 \mathrm{~cm}$, that is, those with the lowest diagnostic accuracy.

Fig. 3 Relazione esistente tra dimensione della lesione e presenza di necrosi: il grafico dimostra come l'incidenza di necrosi si incrementi gradualmente all'aumentare delle dimensioni delle lesioni; la maggior proporzione di necrosi si è riscontrata nelle lesioni di $6 \mathrm{~cm}$, ovvero quelle caratterizzate da minor accuratezza diagnostica.

(from $86 \%$ to $100 \%$ ), achieved with both FNAC and CB. In addition, if we consider only benign lesions, CB has significantly higher accuracy and sensitivity compared with FNAC (accuracy greater than $80 \%$ vs. $50 \%-70 \%$ ) [9, 22-25]. Accuracy and sensitivity levels found in our study are similar to those previously reported for FNAC but fail to reach those reported for $\mathrm{CB}$, a finding that is not contradictory given that only $6.4 \%$ of procedures were carried out with a cutting needle (used alone or in combination with other needles).

Demonstration of definitely malignant cells is proof of the raggiungono $i$ valori riportati dalla $C B$, elemento comunque non contraddittorio dal momento che solo nel $6,4 \%$ delle procedure è stato utilizzato un ago tranciante (singolarmente od in associazione con altri aghi).

La documentazione di cellule sicuramente maligne è, nella pressoché totalità dei casi, prova certa della natura maligna dell'espanso. Nella nostra coorte l'unico caso classificato come maligno (neoplasia di origine epiteliale) e poi risultato benigno (granulomatosi escavata) alla diagnosi finale trova esplicazione nel fatto che la lesione benigna ha sviluppato atipie cellulari tali da farla risultare sospetta all'indagine citologica per espanso di natura maligna.

Nonostante gli insuccessi siano sensibilmente minori per le lesioni maligne, tuttavia si è evidenziato un $11 \%$ di falsi negativi nell'ambito di tali addensamenti (integralmente costituiti da prelievi a punteggio 0-1). In aggiunta, la nostra esperienza indica come la sola ispezione ad occhio nudo del campione ottenuto (in termini di integrità del frustolo bioptico o di cellularità o di carattere ematico del prelievo aspirativo) è inaffidabile nel predirne l'adeguatezza [30,32, 34, 36, 38] ed è quindi auspicabile la presenza dell'anatomopatologo nel corso della seduta bioptica. La ripetizione del prelievo dovrebbe essere presa in considerazione ogni qual volta si verifichi discordanza tra risultato bioptico, presentazione clinica e caratteristiche TC (prima di passare ad accertamenti diagnostici invasivi di II livello) [13].

L'analisi della nostra coorte ha evidenziato come le uniche variabili in grado di influenzare, in termini statisticamente significativi, l'accuratezza diagnostica della metodica siano la diagnosi finale (benignità versus malignità) e le dimensioni della lesione (nodi con diametro medio inferiore ad 1,5 cm o masse di dimensioni superiori a $5 \mathrm{~cm}$ sono $\mathrm{ca}$ ratterizzati da livelli di minore accuratezza diagnostica). Riferendosi a quest'ultimo aspetto, gli studi presenti in letteratura esprimono giudizi discordanti in merito all'influenza delle dimensioni della lesione sui livelli di accuratezza dia- 


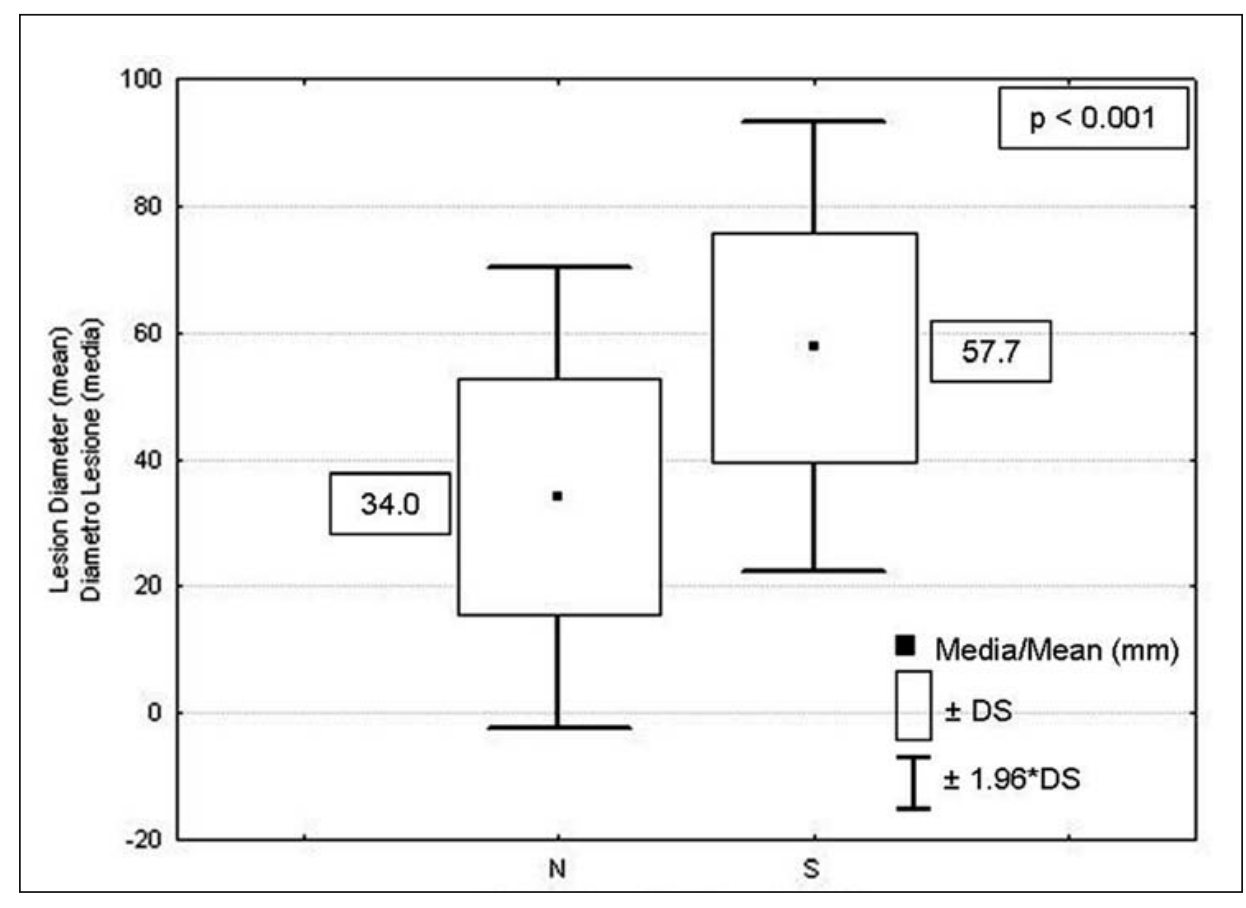

Fig. 4 Box \& Whisker plot shows a significant difference in size in between lesions without $(3.4 \mathrm{~cm} \pm 1.8)$ and with $(5.7 \mathrm{~cm} \pm 1.8)$ central necrosis. Mean size of lesions with and without necrosis differs significantly $(p<0.001)(S D$, standard deviation; $N$, no; $S$, yes).

Fig. 4 Il grafico Box \& Whisker dimostra una differenza significativa in termini di dimensioni nel gruppo di lesioni senza $(3,4$ $\mathrm{cm} \pm 1,8)$ e con necrosi centrale intralesionale $(5,7 \mathrm{~cm} \pm 1,8)$. Il diametro medio delle lesioni in assenza e presenza di necrosi differisce significativamente $(p<0,001)(D S$, deviazione standard; $N, \mathrm{No} ; \mathrm{S}, \mathrm{Si})$.

malignant nature of the mass in virtually all cases. In our cohort, the only case classified as malignant (epithelial neoplasm) at biopsy and found to be benign (excavated granuloma) at final diagnosis is explained by the fact that the lesion had developed cellular atypia that made it suspicious for malignancy at cytological assessment.

Although there were substantially fewer failures in malignant lesions, the false negative rate was $11 \%$ in this group (all for samples with a score of 0-1). In addition, our experience shows that gross inspection of the sample (in terms of integrity of the biopsy specimen, cellularity or blood contamination of the aspirate) is unreliable in predicting adequacy $[30,32,34,36,38]$, making the presence of a pathologist during the biopsy procedure strongly desirable. Repetition of the biopsy should be considered whenever there is discordance between the biopsy result, the clinical presentation and the CT findings (before proceeding to invasive second-line diagnostic investigations) [13].

Analysis of our cohort showed that the only variables capable of significantly affecting diagnostic accuracy are the final diagnosis (benignity vs. malignancy) and lesion size (nodules smaller than $1.5 \mathrm{~cm}$ or masses larger than $5 \mathrm{~cm}$ have lower diagnostic yield). Previous studies have reported conflicting findings with regard to the influence of lesion size on diagnostic accuracy [13, 20, 30, 36, 37]. Tsukada et al. found that diagnostic accuracy declined progressively with decreasing lesion size: from $100 \%$ to $93 \%, 87 \%, 79 \%$ and $67 \%$ for lesions $>5 \mathrm{~cm}, 3-5 \mathrm{~cm}, 2-3 \mathrm{~cm}, 1-2 \mathrm{~cm}$ and $<1 \mathrm{~cm}$, respectively [13]. Lucidarme et al. reported accuracy levels of approximately $88 \%$ for lesions $>2 \mathrm{~cm}$ when the mean number of needle passes was 2.5 , whereas when only a single specimen was obtained, accuracy decreased to $83 \%$ [29].

The results of our study are similar to those reported by Yeow et al. [20], who found, with a mean number of passes of three (without a pathologist present), lower levels of diag- gnostica [13, 20, 30, 36, 37]. Tsukada ha riscontrato un graduale e progressivo decremento dei valori di accuratezza diagnostica man mano che le dimensioni delle lesioni si riducevano: dal 100\% al 93\%, 87\%, 79\% e 67\% per lesioni rispettivamente $>5 \mathrm{~cm}$, tra 3 e $5 \mathrm{~cm}$, tra 2 e $3 \mathrm{~cm}$, tra 1 e $2 \mathrm{~cm}$ $e<1 \mathrm{~cm}$ [13]. Lucidarme ha riscontrato valori di accuratezza di circa l' $88 \%$ per lesioni $>2 \mathrm{~cm}$ con un numero medio di prelievi per biopsia di 2.5, mentre l'accuratezza si riduceva all'83\% in caso di unico prelievo per seduta bioptica [29].

Nel nostro studio si sono ottenuti risultati simili a quelli descritti da Yeow [20] che riportava, con una media di 3 prelievi bioptici a seduta (in assenza di un medico anatomopatologo in sala), livelli inferiori di accuratezza diagnostica per lesioni <1,5 cm e >5 cm (dell' $84 \%$ e 93\% rispettivamente) quando paragonati a lesioni con diametro compreso tra 1,5 e $5 \mathrm{~cm}(96 \%)$. Nel nostro lavoro vengono, invece, riportati valori di accuratezza diagnostica globale (per lesioni maligne e benigne) del $68 \%$ per lesioni $<1,5 \mathrm{~cm}$, del $78 \%$ per lesioni $>5,0 \mathrm{~cm}$ e dell'87\% per le lesioni comprese tra 1,5 e 5,0 cm. La maggior accuratezza diagnostica riportata da Yeow è giustificata dal fatto che in tutti i casi è stata eseguita una $C B$ con tecnica coassiale (caratterizzata da livelli di accuratezza diagnostica maggiori rispetto alla FNAC), mentre nel nostro studio solo il $6 \%$ delle manovre è stato eseguito con tale procedura, riservando la FNAC a tutti gli altri casi. In aggiunta, avendo la disponibilità del citopatologo in sala radiologica, è risultato sensibilmente minore il numero di prelievi per seduta (1,3 prelievi versus 3,0). Il numero di prelievi, essendo variabile nei diversi studi, potrebbe costituire un determinante elemento confondente in grado di influenzare l'accuratezza diagnostica al pari delle dimensioni della lesione [20, 29, 37]. Con una media di 1,3 prelievi per procedura, il nostro studio pone come limite dimensionale critico, al di sotto del quale si verifica una sensibile riduzione di accuratezza diagnostica, il valore di $1,5 \mathrm{~cm}$. Questo risultato è in linea con le 
nostic accuracy for lesions $<1.5 \mathrm{~cm}$ and $>5 \mathrm{~cm}(84 \%$ and $93 \%$, respectively) compared with those between $1.5 \mathrm{~cm}$ and $5 \mathrm{~cm}$ in diameter (96\%). In contrast, overall diagnostic accuracy (for malignant and benign lesions) in our study was $68 \%$ for lesions $<1.5 \mathrm{~cm}, 78 \%$ for those $>5.0 \mathrm{~cm}$ and $87 \%$ for those between $1.5 \mathrm{~cm}$ and $5.0 \mathrm{~cm}$. The higher diagnostic accuracy reported by Yeow et al. is explained by the fact that they used CB with coaxial technique (which is more accurate than FNAC) in all cases, whereas we used CB for only $6 \%$ of procedures and FNAC for the remaining cases. In addition, the presence of the cytopathologist during the procedure substantially reduced the number of needle passes (1.3 vs. 3.0). As the number of needle passes varies among the different studies, it could constitute an important confounding factor capable of affecting diagnostic accuracy to the same extent as lesion size [20, 29, 37]. With a mean number of passes of 1.3 , our study found $1.5 \mathrm{~cm}$ to be the threshold size under which diagnostic accuracy is substantially reduced. This finding is in bearing with the conclusions of Li et al. [11] who, using FNAC with coaxial technique in the presence of a cytopathologist, deduced the same cutoff value. The number of needle passes should, however, be kept to a minimum, as this variable is significantly related to higher rates of pneumothorax [32]; the presence on site of a cytopathologist during the procedure is instrumental to establishing a correct diagnosis.

The substantial reduction in diagnostic accuracy in small lesions could be due to sampling errors resulting from increased technical difficulty in the localisation phase [11]. Such difficulties are further supported by the higher rate of complications within this class of lesions: Yeow et al. [32] reported a 17 times higher risk of pneumothorax and a six times higher risk of bleeding for lesions smaller than $2 \mathrm{~cm}$. In view of the lower diagnostic accuracy for small lung nodules (whether sampled by FNAC or CB) and the higher complication rate, fine-needle aspiration should always be preferred to CB for lesions smaller than $1 \mathrm{~cm}$, as suggested by Laurent et al. and Yeow et al. [30, 20]. When sampling these nodules, in fact, it is impossible to avoid inclusion of portions of healthy aerated lung tissue, as the biopsy core is 1.3$\mathrm{cm}$ long (shortest throw-length setting) [29, 32, 37]. Diffuse bleeding may also occur as a result of the surrounding healthy parenchyma not being able to provide an adequate tamponade effect $[29,32,37]$. Bleeding generally occurs at the first pass and tends to obscure the small pulmonary nodule, making subsequent samplings impossible. Finally, in a nonnegligible number of cases, the material recovered proves inadequate due to the abundant presence of blood. Despite the fact that throw lengths of $10 \mathrm{~mm}$ can be used to avoid bleeding in lesions smaller than $1.5 \mathrm{~cm}$, Boiselle et al. reported a diagnostic accuracy of $62 \%$ with this approach [39]. This value is lower than the $67 \%$ obtained by us with the exclusive use of needle aspiration biopsies for such lesions and with a lower rate of perilesional bleeding.

With regard to the size criterion as a variable affecting diagnostic accuracy, we encountered a decrease in accuracy for lesions larger than $5 \mathrm{~cm}$. This finding is justified by the presence of central necrosis, which is frequent in lung masses $>5 \mathrm{~cm}$ (in our series, the CT rate of tumour necrosis was $0 \%-15 \%$ in lesions up to $5 \mathrm{~cm}$ and $12 \%-41 \%$ in masses $\geq 5$ conclusioni dello studio di Li [11] che, utilizzando la FNAC con tecnica coassiale in presenza del citopatologo, deduce il medesimo cut-off. $\grave{E}$ comunque auspicabile conseguire il minimo numero di campionamenti possibili per procedura dal momento che tale variabile è significativamente correlata ad una maggior proporzione di pneumotoraci [32]; elemento indispensabile, a garanzia dell'obiettivo di ottenere una corretta diagnosi, risulta essere la presenza del citopatologo durante la seduta bioptica.

La sensibile riduzione di accuratezza diagnostica per lesioni di ridotte dimensioni potrebbe trovare una valida esplicazione in errori di campionamento, dovuti a maggiori difficoltà tecniche nella fase di centratura bioptica [11]. Le difficoltà procedurali trovano ulteriore conferma nella maggior proporzione di complicanze riscontrabile in questa categoria di lesioni: Yeow [32] riporta, infatti, un rischio di pneumotorace 17 volte maggiore e di sanguinamento 6 volte superiore per lesioni di diametro inferiore ai $2 \mathrm{~cm}$. In ragione della minor accuratezza diagnostica per $i$ piccoli noduli polmonari (che siano sottoposti a FNAC o a CB) ed alla più alta percentuale di complicanze riscontrate, risulta sempre opportuno preferire alla $C B$, come già suggerito da Laurent e Yeow [20, 30], il prelievo aspirativo con ago sottile per le lesioni di dimensione inferiore al centimetro. Infatti, risulta impossibile evitare, nel campionamento di questi piccoli nodi, porzioni di tessuto aerato sano, dal momento che il frustolo bioptico ha lunghezza pari ad 1,3 cm (limite inferiore della lunghezza dello scatto dell'ago tranciante) [29, 32, 37]. Può inoltre verificarsi un sanguinamento diffuso dal momento che il parenchima circostante sano, interessato anch'esso dal campionamento, non è in grado di fornire un adeguato effetto tampone [29, 32, 37]. La soffusione emorragica si verifica, generalmente, al primo prelievo e tende ad oscurare il piccolo nodo polmonare rendendo impossibile successivi campionamenti. Infine, il materiale ottenuto risulta, con probabilità non trascurabile, inadeguato per la precipua presenza di sangue. Nonostante si possano utilizzare lunghezze di scatto pari a $10 \mathrm{~mm}$ per evitare il sanguinamento in lesioni inferiori ad 1,5 cm, Boiselle ha riportato, in tali condizioni, un'accuratezza diagnostica pari al $62 \%$ [39]. Questo valore risulta inferiore al 67\% da noi ottenuto utilizzando esclusivamente, per tali lesioni, l'agoaspirato e con un tasso di sanguinamento perilesionale di minor entità.

Analizzando il parametro dimensionale, quale variabile determinante l'accuratezza diagnostica della procedura, si sono riscontrati decrementi di accuratezza per lesioni con dimensione maggiore ai $5 \mathrm{~cm}$. Questa evenienza viene compresa se si considera la presenza di necrosi centrale, che risulta di frequente riscontro nelle masse polmonari $>5 \mathrm{~cm}$ (nella nostra casistica percentuale TC di necrosi tumorale per lesioni sino a $5 \mathrm{~cm}$ compresa tra lo $0 \%$ ed il $15 \%$, per masse $\geq 5$ cm tra il $12 \%$ ed il $41 \%$ ). Risulta quindi evidente come, nelle grosse masse polmonari, sia necessario disporre di indagini TC acquisite con infusione di mezzo di contrasto per individuare aree lesionali necrotiche al fine di evitarle durante il campionamento. Inoltre, in assenza di un anatomopatologo in sala, nell'evenienza all'ispezione visiva di frustoli particolarmente fragili e frammentati o di prelievi citologici ottenuti con agoaspirato, particolarmente ematici, si dovrebbero 
$\mathrm{cm})$. It is therefore clear that large lung masses require contrast-enhanced CT imaging to identify necrotic areas and avoid them during the sampling procedure. Moreover, when no on-site pathologist is present and the biopsy cores appear particularly fragile and fragmented or the aspirate particularly bloody on gross inspection, further samples should be obtained taking care to direct the needle to different areas of the lesion [32, 40, 41].

The presence of cavitations within a lung mass does not appear to influence the diagnostic accuracy of either FNAC, as demonstrated in our study, or CB, as shown by Yeow et al. [20]. In our series, diagnostic accuracy was not substantially lower in the 91 cavitated lesions compared with solid masses. Similarly, diagnostic accuracy was not significantly affected by the presence of calcification or a frankly necrotic centre; by lesion depth (from the pleural surface), morphology or location; or by the occurrence of complications such as pneumothorax and bleeding. No evaluation was made with regard to needle size or the radiologist's experience, variables that are ascribed different significance in the various studies [20, 41].

\section{Conclusions}

In conclusion, transthoracic CT-guided needle biopsy of pulmonary lesions is a highly accurate procedure, especially in malignant lesions. However, to enhance the likelihood of success and achieve a correct diagnosis, awareness of the variables affecting its effectiveness is crucial: benign lesions, nodules smaller than $1.5 \mathrm{~cm}$ and masses larger than $5 \mathrm{~cm}$ are associated with substantially lower accuracy rates. This conclusion applies to settings that implement a standard biopsy protocol, with an on-site cytopathologist present and 1.3 passes per procedure. eseguire ulteriori campionamenti avendo cura di direzionare l'ago in diverse regioni della lesione [32, 40, 41].

La presenza di franche cavitazioni, nel contesto di una massa polmonare, non risulta influenzare l'accuratezza diagnostica sia della FNAC, come dimostrato dal nostro studio, sia della CB, come evidenziato da Yeow [20]. Nella nostra coorte, tra le 91 lesioni cavitate non si sono evidenziati valori di accuratezza diagnostica sensibilmente inferiori rispetto alle masse solide. Analogamente, la presenza di calcificazioni o di centro francamente necrotico, od ancora la profondità della lesione (rispetto al piano pleurico) o la morfologia o la localizzazione od infine la comparsa di complicanze, quali lo pneumotorace od il sanguinamento, non hanno significativamente alterato $i$ valori di accuratezza diagnostica della procedura. Non si sono, invece, formulate valutazioni relative al calibro dell'ago o all'esperienza del radiologo prelevatore, parametri che assumono, a seconda dei diversi studi presenti in letteratura, significato diverso [20, 41].

\section{Conclusioni}

In conclusione, l'agobiopsia transtoracica TC guidata di espansi polmonari è metodica ad elevata accuratezza diagnostica, specie per le lesioni di natura maligna. Risulta comunque indispensabile, al fine di implementare le probabilità di successo della procedura in termini di raggiungimento della corretta diagnosi, la conoscenza delle variabili in grado di inficiare tale efficacia: le lesioni benigne ed i nodi di dimensioni minori ad $1,5 \mathrm{~cm}$ o le masse superiori a $5 \mathrm{~cm}$ sono correlate a valori di accuratezza diagnostica sensibilmente inferiori. Tale affermazione è da ritenersi valida nel contesto di un protocollo bioptico standard, in presenza del citopatologo durante la seduta bioptica e per l'esecuzione di 1,3 prelievi per procedura.

\section{References/Bibliografia}

1. Klein JS, Zarka M (2000) Transthoracic needle biopsy. Radiol Clin North Am 38:235-266

2. Priola SM, Priola AM, Cardinale L et al (2006) The anterior mediastinum: Anatomy and imaging procedures. Radiol Med 111:295-311

3. Priola AM, Priola SM, Cardinale L et al (2006) The anterior mediastinum: Diseases. Radiol Med 111:312-342

4. Screaton NJ, Flower CDR (2000) Percutaneous needle biopsy of the pleura. Radiol Clin North Am 38:293-301

5. Haaga JR, Alfidi RJ (1976) Precise biopsy localization by computed tomography. Radiology 118:603-607
6. Romano M, Griffo S, Gentile M et al (2004) CT guided percutaneous fine needle biopsy of small lung lesions in outpatients. Safety and efficacy of the procedure compared to inpatients. Radiol Med 108:275-282

7. Westcott JL (1988) Percutaneous transthoracic needle biopsy. Radiology 169:593-601

8. van Sonnenberg E, Lin AS, Deutsch AL et al (1983) Percutaneous biopsy of difficult mediastinal, hilar, and pulmonary lesions by computed tomographic guidance and a modified coaxial technique. Radiology 148:300-302
9. Stanley JH, Fish GD, Andriole JG et al (1987) Lung lesions: cytologic diagnosis by fine needle biopsy. Radiology 162:389-391

10. Khouri NF, Stitik FP, Erozan YS et al (1985) Transthoracic needle aspiration biopsy of benign and malignant lung lesions. AJR Am J Roentgenol 144:281-288

11. Li H, Boiselle PM, Shepard JO et al (1996) Diagnostic accuracy and safety of CT-guided percutaneous needle aspiration biopsy of the lung: comparison of small and large pulmonary nodules. AJR Am J Roentgenol 167:105-109 
12. Larscheid RC, Thorpe PE, Scott W (1998) Percutaneous transthoracic needle aspiration biopsy: a comprehensive review of its current role in the diagnosis and treatment of lung tumors. Chest 114:704-709

13.Tsukada H, Satou T, Iwashima A et al (2000) Diagnostic accuracy of CTguided automated needle biopsy of lung nodules. AJR Am J Roentgenol 175:239-243

14. Perlmutt LM, Johnston WW, Dunnick NR(1989) Percutaneous transthoracic needle aspiration: a review. AJR Am J Roentgenol 152:451-455

15. Kazerooni EA, Lim FT, Mikhail A et al (1996) Risk of pneumothorax in CTguided transthoracic needle aspiration biopsy of the lung. Radiology 198:371-375

16. Tomiyama N, Yasuhara Y, Nakajima Y et al (2006) CT-guided needle biopsy of lung lesions: A survey of severe complication based on 9783 biopsies in Japan. Eur J Radiol 59:60-64

17. Westcott JL, Rao N, Colley DP (1997) Transthoracic needle biopsy of small pulmonary nodules. Radiology 202:97-103

18. Golfieri R, Sbrozzi F, De Santis F et al (1998) CT-guided transthoracic needle biopsy: clinical role in the diagnosis of solitary pulmonary nodules. Radiol Med 95:329-337

19. Swischuk JL, Castaneda F, Patel JC et al (1998) Percutaneous transthoracic needle biopsy of the lung: review of 612 lesions. J Vasc Intervent Radiol 9:347-352

20. Yeow KM, Tsay PK, Cheung YC et al (2003) Factors affecting diagnostic accuracy of CT-guided coaxial cutting needle lung biopsy: retrospective analysis of 631 procedures. J Vasc Intervent radiol 14:581-588

21. Nordenström B (1965) A new technique for transthoracic biopsy of lung changes. Br J Radiol 38:550-553
22. Kim HK, Shin BK, Cho SJ et al (2002)

Transthoracic fine needle aspiration and core biopsy of pulmonary lesions. A study of 296 patients. Acta Cytol 46:1061-1068

23. Bocking A, Klose CK, Kyll HJ et al (1995) Cytrologic versus histologic evaluation of needle biopsy of the lung, hilum and mediastinum. Acta Cytol 39:463-471

24. Greif J, Marmur S, Schwarz Y et al (1998) Percutaneous core cutting needle biopsy compared with fine-needle aspiration in the diagnosis of peripheral lung malignant lesions. Cancer Cytopathol 84:144-148

25. Sagel SS, Ferguson TB, Forrest JV et al (1978) Percutaneous transthoracic aspiration needle biopsy. Ann Thorac Surg 26:399-405

26. Austin JHM, Cohen MB (1993) Value of having a cytopathologist present during percutaneous fine-needle aspiration biopsy of lung: report of 55 cancer patients and metaanalysis of literature. AJR Am J Roentgenol 160:175-177

27. Nasuti JF, Gupta PK, Zubair WB (2002) Diagnostic value and cost-effectiveness of on site evaluation of fine-needle aspiration specimens: review of 5.688 cases. Diagn Cytopathol 27:1-4

28. Stewart CJ, Stewart IS (1996) Immediate assessment of fine needle aspiration cytology of lung. J Clin Pathol 49:839-843

29. Lucidarme O, Howart N, Finet JF et al (1998) Intrapulmonary lesions: percutaneous automated biopsy with a detachable, 18-gauge, coaxial cutting needle. Radiology 207:759-765

30. Laurent F, Latrabe V, Vergier B et al (2000) CT-guided biopsy of the lung: comparison between aspiration and automated cutting needles using a coaxial technique. Cardiovasc Intervent Radiol 23:266-272

31. Tomiyama N, Mihara N, Maeda M et al (2000) CT-guided needle biopsy of small pulmonary nodules: value of respiratory gating. Radiology 217:907-910
32. Yeow KM, See LC, Lui KW et al (2001)

Risk factors for pnemothorax and bleeding after CT-guided percutaneous coaxial cutting needle biopsy of lung lesions. J Vasc Interv Radiol 12:1305-1312

33. Lopez Hanninen E, Vogl TJ, Ricke J et al (2001) CT-guided percutaneous core biopsies of pulmonary lesions.

Diagnostic accuracy, complications and therapeutic impact. Acta Radiol 42:151-155

34. Laurent F, Michel P, Latrabe V et al (1999) Pneumothoraces and chest tube placement after CT-guided transthoracic lung biopsy using a coaxial technique: incidence and risk factors. AJR AM J Roentgenol 172:1049-1053

35. Cox JE, Chiles C, McManus CM et al (1999) Transthoracic needle aspiration ariables that affect risk of pneumothorax. Radiology 212:165-168

36. Ko JP,Shepard JO, Drucker EA et al (2001) Factors influencing pneumothorax rate at lung biopsy: are dwell time and angle of pleural puncture contributing factors? Radiology 218:491-496

37. Klein JS, Salomon G, Stewart EA (1996) Transthoracic needle biopsy with a coaxially placed 20 -gauge automated cutting needle: results in 122 patient. Radiology 198:715-720

38. Arakawa H, Nakajima Y, Kurihara Y et al (1996) CT-guided transthoracic needle biopsy: a comparison between automated biopsy gun and fine needle aspiration. Clin Radiol 51:503-506

39. Boiselle PM, Shepard JA, Mark EJ et al (1997) Routine addition of an automated biopsy device to fine-needle aspiration of the lung. AJR Am J Roentgenol 169:661-666

40. Moore EH (1998) Technical aspects of needle aspiration lung biopsy: a personal perspective. Radiology 208:303-318

41. Wagner HJ, Barth P, Schade-Brittinger C et al (1995) Postmortem evaluation of four randomly selected automated biopsy devices for transthoracic lung biopsy. Cardiovasc Intervent Radiol 18:300-306 